\title{
Excitotoxins, Mitochondrial and Redox Disturbances in Multiple Sclerosis
}

\author{
Cecilia Rajda ${ }^{1}$, Dániel Pukoli ${ }^{1,2}$, Zsuzsanna Bende ${ }^{1}$, Zsófia Majláth ${ }^{1}$ and László Vécsei ${ }^{1,3, *}$ \\ 1 Department of Neurology, University of Szeged, 6725 Szeged, Hungary; \\ rajda.cecilia@med.u-szeged.hu (C.R.); pukoli.daniel@med.u-szeged.hu (D.P.); bendzsu@gmail.com (Z.B.); \\ majlathzsofia@gmail.com (Z.M.) \\ 2 Department of Neurology, Vaszary Kolos Hospital, 2500 Esztergom, Hungary \\ 3 MTA-SZTE Neuroscience Research Group, 6725 Szeged, Hungary \\ * Correspondence: vecsei.laszlo@med.u-szeged.hu; Tel.: +36-62-545-351; Fax: +36-62-545-597
}

Academic Editors: Christoph Kleinschnitz and Sven Meuth

Received: 12 October 2016; Accepted: 22 January 2017; Published: 8 February 2017

\begin{abstract}
Multiple sclerosis (MS) is a chronic inflammatory disease of the central nervous system (CNS). There is increasing evidence that MS is not only characterized by immune mediated inflammatory reactions, but also by neurodegenerative processes. There is cumulating evidence that neurodegenerative processes, for example mitochondrial dysfunction, oxidative stress, and glutamate (Glu) excitotoxicity, seem to play an important role in the pathogenesis of MS. The alteration of mitochondrial homeostasis leads to the formation of excitotoxins and redox disturbances. Mitochondrial dysfunction (energy disposal failure, apoptosis, etc.), redox disturbances (oxidative stress and enhanced reactive oxygen and nitrogen species production), and excitotoxicity (Glu mediated toxicity) may play an important role in the progression of the disease, causing axonal and neuronal damage. This review focuses on the mechanisms of mitochondrial dysfunction (including mitochondrial DNA (mtDNA) defects and mitochondrial structural/functional changes), oxidative stress (including reactive oxygen and nitric species), and excitotoxicity that are involved in MS and also discusses the potential targets and tools for therapeutic approaches in the future.
\end{abstract}

Keywords: biomarker; excitotoxin; glutamate; oxidative stress; mitochondria; multiple sclerosis; neurodegeneration

\section{Introduction}

Multiple Sclerosis (MS) is an inflammatory central nervous system (CNS) disorder associated with demyelination and neurodegeneration, which cause temporary or permanent neurological symptoms [1]. Previous opinions suggested that the initial process of the disease was inflammation, followed later by neurodegenerative mechanisms, including oxidative stress, neuronal and oligodendrocyte (ODC) apoptosis. Recent research has provided data that neurodegeneration does not follow inflammation, but that it is present simultaneously and related [2,3]. One of the connecting links between inflammation and neurodegenerative mechanisms is glutamate excitotoxicity [4,5]. In MS, involvement of both white and gray matter is well known. Peculiar pathological patterns of white matter lesions are infiltration of immune cells (lymphocytes, macrophages, and microglia), Ig and complement deposition, ODC death, demyelination, axonal loss, and astrogliosis. Their occurrences in a white matter lesion depend on the lesion's activity and pathologic profile [2,6-8]. Gray matter lesions have been associated with clinical disability and cognitive impairment [8-10]. They are characterized by an intact blood-brain barrier (BBB), the absence of lymphocyte infiltration, antibody deposits, and complements, therefore, grey matter lesions are considered mainly "non-inflammatory" [8,9,11-13]. Several reports suggest that both inflammatory and neurodegenerative processes contribute to the pathology of grey matter 
but their relationship is unexplained. According to a relatively new theory (the so-termed "inside-out" theory), a primary cytodegeneration of ODCs and/or neurons would appear initially years before the first symptoms, and the autoimmune inflammatory reaction would direct against the autoantigens released during cellular degeneration [3,9]. More plausible hypothesis is that adaptive immune processes provoke white and grey matter damage, and when pathological changes like axon damage and axonal loss have accessed a serious level, neurodegeneration takes over from the inflammatory course [9].

Extensive neuroimaging, immunohistochemical [8] and pathological studies are searching for the answers about whether the gray and white matter lesions are affected by the same mechanism. One hypothesis presumes retrograde degeneration secondary to the white matter lesion, but there are evidences of demyelination-independent grey matter damages in experimental autoimmune encephalomyelitis (EAE)/MS [9,14].

The chronic inflammatory process present in MS results in elevated levels of reactive oxygen species, which may lead to mitochondrial damage and consequently an energy deficit in neurons [15]. An energy deficit and chronic demyelination lead to several ion channel dysfunctions. Alterations in Glu homeostasis may result in excessive calcium influx to the cells, which may cause excitotoxic neuronal damage [15].

\section{Excitotoxicity in Multiple Sclerosis}

Glutamate (Glu) is one of the principal excitatory neurotransmitters in the CNS. All types of cells, including neurons and glial cells (oligodendrocytes, astrocytes, microglia) use it to communicate with each other [4]. Its level in the CNS is almost a thousand-fold higher than other neurotransmitters and it can rise another 55-fold [5]. Under normal conditions, the presynaptic vesicles release Glu into the synaptic cleft. Because of its toxicity, it must be cleared away quickly before it accumulates. Astrocytes are mainly involved in the reuptake of Glu via Glu transporters and in its conversion to glutamine, a non-excitatory amino acid, via the glutamine synthetase pathway [16]. In the Glu-glutamine cycle, the main enzymes involved are glutaminase and glutamine-synthetase $[17,18]$. Glu and its metabolism are present in white matter (WM) too. ODCs have glutamine synthetase activity [19] and produce Glu dehydrogenase $[6,20]$. Microglia, the main source of extracellular Glu uses glutaminase to produce it from glutamine [21].

The concept of Glu excitotoxicity in the CNS was established by Olney in 1969 [22], who injected monosodium Glu in newborn mice and observed acute neuronal necrosis. In excitotoxicity, excessive stimulation of Glu-binding receptors by extracellular Glu dispatches the intracellular cascade mechanisms-which lead to cell death.

Alterations in Glu homeostasis were observed both in MS and EAE. Stover et al. (1997) [23] was the first to provide evidence for the participation of Glu excitotoxicity in MS: they found a significantly elevated Glu level in the cerebrospinal fluid (CSF) of MS patients in the acute phase of the disease (data are shown in Table 1). Sarchielli and colleagues measured elevated Glu levels in MS patients' CSF, in different stages of disease (see Table 2) [24]. In 2005, Srinivasan et al. showed increased Glu levels with MR spectroscopy in acute lesion of MS patients [25]. There was a correlation between the Glu level and the extension of axonal injury [26]. In EAE, aberrations in the expression of Glu transporters, receptors or metabolizing enzymes were detected which suggested the role of excitotoxicity in this model of MS. Pathological changes like axonal damage, demyelination, and ODC loss were observed which are exhibitive of excitotoxicity. The use of GluR antagonists could suspend these effects and cause disease amelioration [6,27-31]. 
Table 1. Comparison of Glu and its non-active form, glutamine levels in patient cerebrospinal fluid (CSF) samples with different kinds of disorders. Results compared with controls and peripheral facial nerve palsy patients are significant ${ }^{*} p<0.05$. (Data of Stover et al., 1997 [23]).

\begin{tabular}{ccc}
\hline Patient Groups & Glutamate Levels in CSF $(\mu \mathbf{M})$ & Glutamine Levels in CSF $(\mu \mathbf{M})$ \\
\hline Controls, $n=20$ & $1.3 \pm 0.1$ & $574 \pm 25$ \\
Facial palsy, $n=5$ & $1.0 \pm 0.1$ & $570 \pm 54$ \\
MS (non-active disease), $n=14$ & $1.2 \pm 0.1$ & $467 \pm 47$ \\
MS (active disease), $n=21$ & $3.3 \pm 0.3^{*}$ & $528 \pm 22$ \\
Meningitis, $n=14$ & $2.8 \pm 0.2^{*}$ & $587 \pm 35$ \\
Myelopathy, $n=15$ & $3.1 \pm 0.3^{*}$ & $597 \pm 54$ \\
Stroke, $n=8$ & $2.2 \pm 0.2^{*}$ & $655 \pm 31$ \\
NPH, $n=6$ & $1.7 \pm 0.2^{*}$ & $615 \pm 48$ \\
Epilepsy, $n=4$ & $5.0 \pm 1.8^{*}$ & $629 \pm 84$ \\
\hline
\end{tabular}

Table 2. Glu levels in CNS at different stages of disease and control (measured from patient CSF collected by LP) Data of Sarchielli et al., 2003 [24].

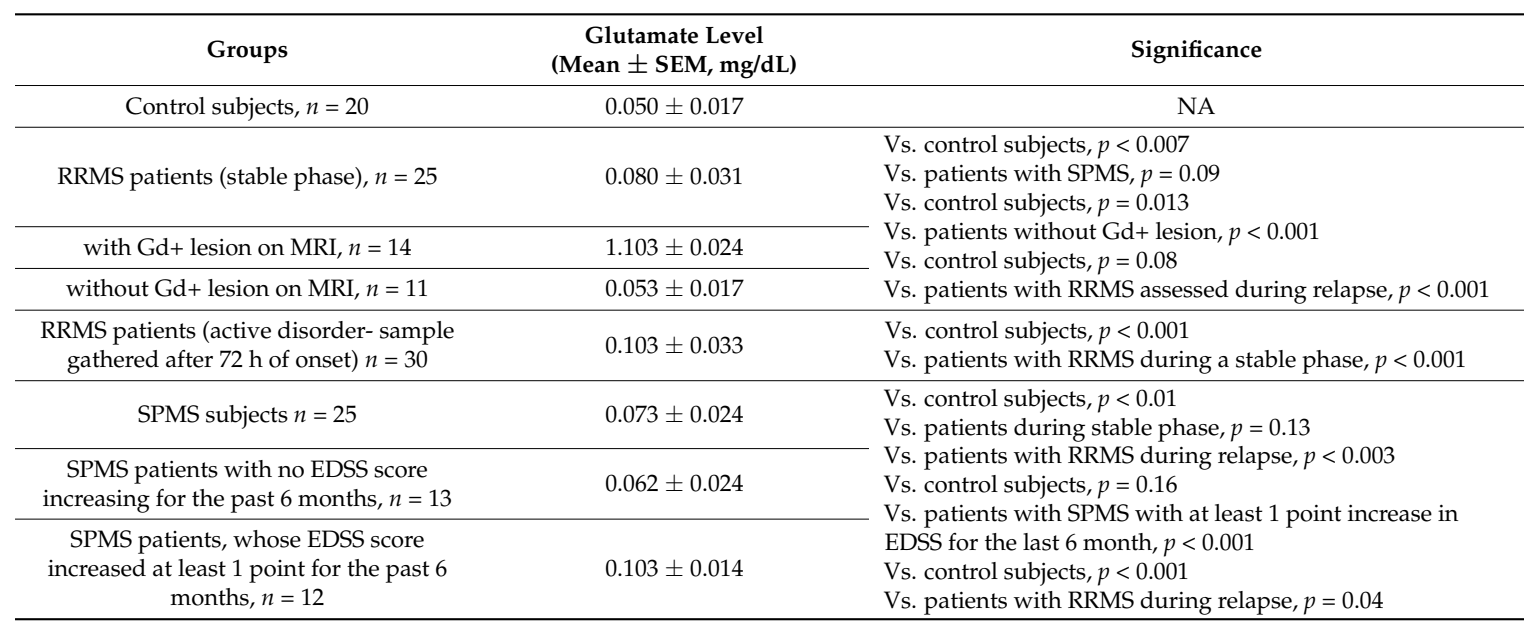

Previous knowledge about glutamate excitotoxicity applied principally to grey matter (GM) pathology. However Glu impacts not only in GM, but WM too [8], so attention has turned toward WM processes, because the injuries in MS involve mainly this part of the CNS [4,32]. The main cell type found here are the ODCs [27]. In MS, the chief WM pathological changes include ODC death and axonal degeneration [7], in which excitotoxicity has high priority [6]. In MS/EAE, there are pathologic changes in almost all parts of Glu homeostasis [27] caused by endogenic (genetic) or exogenic (environmental) triggers [5,27]. Because of these alterations, the rapid elimination of Glu is not possible. Excessive accumulation of this neurotransmitter is toxic to the cells $[4,33]$. The GM pathology in MS/EAE received little attention until recently, when extensive histological studies, proteomic investigations, MRI imaging techniques, and animal model research showed evidence of an independent (or at least partly independent) pathological change in brain cortical regions in both MS and EAE [8,32,34]. Besides axonal damage and retrograde neuronal loss, early damage in synaptic functioning with synaptic loss, called synaptopathy occurs. It has a long-lasting impact on motor and cognitive function of MS patients. Synaptopathy and neuronal damage, in addition to axonal injury, are primarily responsible for patients' disability $[9,34]$. The exact processes causing synaptopathy are not known, but Glu excitotoxicity might have a substantial role in it [34].

Various kind of molecular and cell mechanisms are responsible for the extensive Glu release (Table 3). They involve elevated Glu production by different types of CNS and activated immune cells, altered transporter function, glutamate receptor overexpression, and enzyme defects both in WM and GM [6]. 
Table 3. Causes of elevated extracellular Glu levels in CNS in MS/EAE.

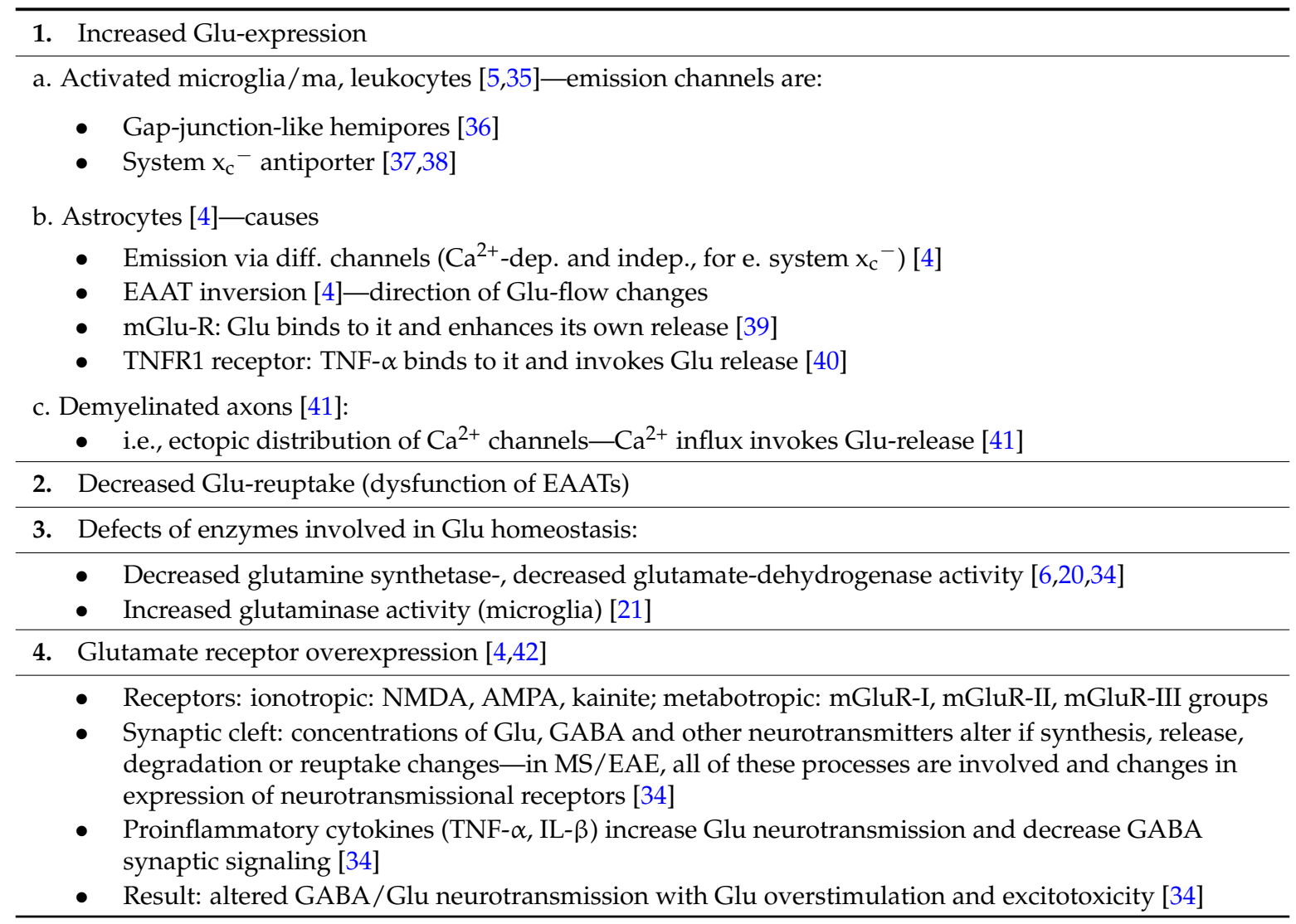

The first and most important sources of extracellular Glu are the activated microglia/macrophage cells and leukocytes [5,35]. At the onset of the disease microglia activation is an important protective mechanism (the cells potentiate tissue repair and disposal of misfolded proteins), but in the chronic phase of MS/EAE it will be deleterious and subserve neuronal death [5]. Microglia cells are activated in all subtypes of MS [43] and they release a great amount of Glu to induce inflammation [35]. Microglia have very low or no glutamine synthetase activity [44], so they require glutamine uptake from the extracellular space to produce Glu. These cells have high glutaminase activity [21]. They discharge Glu into the extracellular space via gap junction-like hemipores [36] and system $\mathrm{x}_{\mathrm{c}}{ }^{-} \mathrm{cystine}_{\mathrm{Glu}}$ antiporters $\left(\mathrm{x}_{\mathrm{c}}{ }^{-}\right)[37,38]$, which transport cystine into the cell converting it to Glu while elevating the extracellular Glu level. The cell will produce glutathione, a potent antioxidative agent from cystine [45].

To worsen the situation, microglia (and in a lesser manner astrocytes too) release tumor necrosis factor alpha (TNF- $\alpha$ ), a proinflammatory cytokine, which plays an important role in microglia-mediated Glu emission [21]. It enhances Glu excitotoxicity by decreasing the expression of EAATs and detoxifying enzymes in glial cells, which lowers the possibility of reuptake of further Glu and increases ionotropic GluRs' localization in synapses $[5,46,47]$. In an in vitro study, TNF- $\alpha$ upregulated the glutaminase 1 isoform in human neuronal cell culture [48].

Recent studies have revealed that astrocytes can not only take up Glu, but also emit it in a $\mathrm{Ca}^{2+}$-dependent and/or -independent manner, i.e., with $\mathrm{x}_{\mathrm{c}}{ }^{-}$antiporter, or with Glu transporters (excitatory amino acid transporters = EAATs), if they change transport direction [4,49]. With a self-perpetuating mechanism, Glu can increase its self-production via metabotropic Glu receptors in these cells [39]. TNF- $\alpha$ can promote Glu delivery by binding to astrocyte TNFR-1 receptors [40]. Aggravating the impact of excitotoxicity, the demyelinated axons may emit additional amounts of Glu. Ectopically distributed $\mathrm{Ca}^{2+}$ channels will appear on the injured axon membrane and, due to pathological $\mathrm{Ca}^{2+}$ influx, Glu will be liberated from vesicles [41]. $\mathrm{Na}^{+}$-dependent Glu transporters will 
activate in the reverse direction which results in Glu ejection into the extracellular space [50]. With this Glu release, the damaged axon turns against itself and will enhance further injury by intensifying glutamate excitotoxicity in a vicious cycle.

In the CNS, to prevent the toxic effects of Glu, fast reuptake of the neurotransmitter from the synaptic cleft is required $[4,16]$. Reuptake is assisted by the electrochemical gradient of Glu across the plasma membrane and is accomplished by Glu transporter proteins, i.e., EAATs. These transporter proteins are expressed mainly by astrocytes, but they can also be found on ODC, neuron, and microglia membranes [16]. In WM, ODCs are primarily responsible for the removal of extracellular Glu [20]. Presently five different families of EAATs are known (EAAT1-EAAT5). They vary in $\mathrm{Na}^{+}$and/or $\mathrm{K}^{+}$ coupling abilities. Their names differ according to whether the transporter is found in human or in other mammals (see Table 4).

Table 4. Glu transporters in human and mammals and their occurrence in CNS cells.

\begin{tabular}{ccc}
\hline Transporter (Human) & Transporter (Mammals) & Occurrence (Cell) \\
\hline EAAT1 & GLAST & Astrocyte, ODC, microglia \\
EAAT2 & GLT-1 & Astrocyte, ODC \\
EAAT3 & EAAC1 & Neuron (somatodendritic), astrocyte (low) \\
EAAT4 & EAAT4 & Purkinje cell \\
EAAT5 & EAAT5 & Müller cell (retina) \\
\hline
\end{tabular}

EAAT: excitatory amino acid transporter; GLAST: Glu-aspartate transporter; GLT-1: glial transporter-1; EAAC: excitatory amino acid carrier; ODC: oligodendrocyte (adapted from Kostic et al., 2013 [4]).

Under pathological circumstances like MS, compensatory EAAT overexpression guarantees the riddance of Glu, as found in EAE [51]. Dysfunction of the transporters leads to extracellular Glu accumulation and consecutive excitotoxicity. In MS lesions, decrease in EAAT2 levels extends from the center to the edge of the lesion, while the EAAT1 and -3 levels are normal [6]. In vitro and in vivo experiments proved that glial transporter-1 (GLT-1) hinders ODC death and axonal degeneration. This effect could be suspended by using $\alpha$-amino-3-hydroxy-5-methyl-4-isoxazolepropionic acid receptor (AMPA) antagonists [52]. Other studies give controversial results about the role of the EAATs in MS/EAE pathology and their role in eliminating Glu [53,54]—on the one hand their downregulation is presumed to cause elevated Glu levels, but on the other hand a lot of data are available for their overexpression [4,20,55]. More research is required to clarify their role.

In human ODCs and in EAE brain, glutamine synthetase and Glu dehydrogenase activity are reduced $[6,20]$. In chronic lesions, minimal function of these enzymes was revealed in astrocytes and microglia [6]. This dysfunction of Glu metabolizing enzymes, which inhibits the OCDs from getting rid of Glu, enhances the damage caused by Glu excitotoxicity long after the inflammation ceases [4]. The cause of the enzyme defect in ODC is unknown; cytokines and oxidative stress may take part in it. Glutamine synthetase is highly susceptible to oxidative injury [4]. However, the glutaminase enzyme is upregulated both in active MS lesions and in EAE [42,56-58] which leads to elevated Glu synthesis. As the greatest amount of Glu is expressed by microglia, inhibiting microglial glutaminase could lower extracellular Glu levels and attenuate excitotoxic effects. Unfortunately, up to now, there has been no potent glutaminase inhibitor available. In 2014 Thomas and colleagues developed a cell-based microglia activation assay for the evaluation of glutamate-levels and microglia glutaminase activity, and to demonstrate its expedience in investigating the effects of glutaminase inhibitors. In their study, they found decreased Glu levels in the presence of the glutaminase inhibitors bis-2-(5-phenylacetimido-1,2,4-thiadiazol-2-yl)ethyl sulfide (BPTES), JHU-198 and JHU-212. The same decrease was noticed in the absence of glutamine. They suggest the use of this microglia assay in developing potent glutaminase inhibitors [21].

Glu exerts its effect by binding glutamate receptors (GluRs) which initiate a signaling cascade inside the cell resulting in apoptosis [4]. The receptors are classified into two groups: ionotropic and metabotropic. Ionotropic receptors are voltage-gated ion channels, which allow $\mathrm{Ca}^{2+}$ or $\mathrm{K}^{+}$to enter the 
cells and initiate downstream signaling [5], while metabotropic Glu receptors are atypical G-protein associated receptors.

Glutamate ionotropic receptors (iGluRs) are divided into NMDA-, AMPA- and kainate receptor subtypes. They are named after their favorable agonist, $N$-methyl-D- aspartate (NMDA), $\alpha$-amino-3-hydroxy-5-methyl-4-isoxazolepropionicacid (AMPA) and kainic acid (kainate).

Metabotropic receptors are categorized into three groups, mGLuR I, mGLuR II, and mGluR III. These receptors can be found on neurons, ODCs, and axons too [42]. They commence second messenger pathways, for example phospholipase $\mathrm{C}$, phosphoinositide 3 kinase/retrovirus AK thymoma/mTOR (PI3K/AKT/mTOR), and mitogen-activated protein kinase (MAPK) signaling [5]. They are classified into three group (mGluR-I, -II, and -III) [4]. Details can be seen in Table 5.

Table 5. Classification of metabotropic Glu receptors.

\begin{tabular}{ccc}
\hline \multicolumn{1}{c}{ Groups } & Subtypes & Localization \\
\hline Group I. & mGlu1, mGlu5 & $\begin{array}{c}\text { Neurons: } \\
\text { postsynaptic (excitatory effect) } \\
\text { Normal case: somatodendritic } \\
\text { OPC }\end{array}$ \\
\hline Group II. & mGlu2, mGlu3 & In MS/EAE: WM, axons \\
\hline Group III. & mGlu4, mGlu6, mGlu7, mGlu8 & Neurons: presynaptic (inhibitor) \\
\hline $\begin{array}{l}\text { mGlu: metabotropic Glu receptor; OPC: oligodendroglia precursor cell; MS: multiple sclerosis; EAE: experimental } \\
\text { autoimmune encephalomyelitis (adapted from Kostic, 2013 [4]). }\end{array}$
\end{tabular}

In CNS, NMDA receptors are found mainly in neurons, making them the most sensitive for glutamate excitotoxicity [4]. In circumstances of normal synaptic transmission, the activated receptor allows $\mathrm{Ca}^{2+}$ through its ion channel only for a short time, then the channel becomes blocked by $\mathrm{Mg}^{2+}$, preventing the cell from excessive $\mathrm{Ca}^{2+}$ overload [59]. In pathological conditions like MS, this mechanism diminishes, allowing $\mathrm{Ca}^{2+}$ influx into the cell [4].

In 2005 Káradottír found functional NMDA receptors on ODC cells in EAE rat brain [60]. These receptors were localized on myelin-forming projections. Their role in ODC is presumed to help myelination. Where only little cytoplasm is present in the projections, low levels of ion influx cause significant ion-concentration elevation with more severe damage (swelling and demyelinating) [60]. NMDA receptors have greater Glu-affinity than $\alpha$-amino-3-hydroxy-5-methyl-4-isoxazolepropionic acid receptors (AMPARs). In neurodegenerative disorders (like MS/EAE), where prolonged Glu release is less common, $N$-methyl-D-aspartate receptors (NMDARs) are more likely to be activated than AMPARs, and NMDARs localized on ODCs are less sensitive to $\mathrm{Mg}^{2+}$ blockades, thus are much more susceptible to glutamate excitotoxicity [60]. These results raise the question whether NMDARs exist on human ODCs or not. In 2016, Livesey et al. examined human ODC progenitor cells in all stages of development. They could not demonstrate any response to NMDA, but that effect may be a result of the maintenance conditions of the cell cultures [61]. Further research is needed to disclose the importance of these kinds of receptors in MS/EAE pathology.

In the human and rodent CNS, AMPARs are found mainly on glial cells including ODCs. They are responsible for high-speed excitatory neurotransmission [4]. Ion permeability of these receptors depends on subunit arrangement, leaking $\mathrm{Na}^{+}, \mathrm{K}^{+}$, and/or $\mathrm{Ca}^{2+}$ ions. GluA2 subunit is highly relevant, its presence in the receptor composition means a loss of $\mathrm{Ca}^{2+}$-permeability [59]. In animal studies there is much evidence to suggest the role of AMPARs in EAE pathology with lowered ODC viability and axonal damage.

Matute et al. (1997) demonstrated that activated AMPARs lower the ODCs' viability in rat ODC cell culture, but this effect can be diminished by the extraction of $\mathrm{Ca}^{2+}$ from the cell medium [62]. By blocking 
the receptors with the antagonist NBQX (2,3-dihydroxy-6-nitro-7-sulfamoyl-benzo(f)uinoxaline2,3-dione), the symptoms of EAE improved with the reduction of ODC death and axonal damage $[28,63]$. In vivo GLT-1 block enhanced ODC death and axonal injury, but the effect could be suspended by AMPA-antagonists [52]. Axonal damage is induced by neuronal AMPARs [64]. However, Wosik et al. (2004) demonstrated low or missing AMPA/kainate receptor expression in in vitro human cell culture and in human brain sections [65]. In their opinion, whilst rodent ODCs produce high levels of AMPARs and have great vulnerability to Glu excitotoxicity, human cells exposed to long-continued dosages of agonists do not have this property and they resist AMPA/kainate-mediated excitotoxicity. If they are present in vivo, it goes against the presumption that Glu excitotoxicity plays a part in the initial damage of myelin-forming ODCs in EAE and MS lesions. In response to these findings Livesey et al. (2016) [61] examined similarities and differences between rodent and human ODC membrane components, receptors, and features in different stages of development. They revealed AMPAR expression in all studied cells including mature ODCs. Their results showed corresponding features and regulation of AMPARs in rodent and human cells. Another question to be answered regards the components of AMPA receptors expressed on OCDs. The presence of the GluA2 subunit results in impermeability to $\mathrm{Ca}^{2+}$. Immunostaining examination revealed a predomination of GluA2-free, $\mathrm{Ca}^{2+}$ permeable AMPA receptors in ODCs found in MS lesions [42]. A study with GluA3 knock-out mice confirmed this result [66]. These findings support the relevancy of AMPA receptors in the pathology of MS/EAE.

In an animal model of MS, Centonze and colleagues examined synaptic changes. They found that excessive Glu accumulation activated AMPAR but not NMDAR, which led to increased excitatory postsynaptic currents (EPSCs) and altered synaptic function [14,67].

Kainate receptors localized on pre- and postsynaptic membranes take part in synaptic signal transduction. Generally it is associated with AMPA [4]. In WM, functional kainate receptors are expressed on the surface of ODCs [4]. The role of these receptors in MS/EAE was first proposed by Matute in 1998, who injected kainate into the rat optic nerve and observed MS-like lesions [68]. Alberdi et al. (2006) revealed that in humans ODCs exposed to kainate and AMPA antagonist GYKI53655, intracellular $\mathrm{Ca}^{2+}$ overloads caused cell death [69]. Activation of kainate receptors by Glu induces sensitivity to complement toxicity in ODCs, which could be another important factor in demyelination in MS/EAE. Kainate receptors can be found on axons too, resulting in axonal degeneration by $\mathrm{Ca}^{2+}$ influx into the axon when they are activated [64]. These receptors are only partially involved in the pathology of MS/EAE and cannot initiate glutamate excitotoxicity per se. Examinations with selective kainate antagonists (UBP296, ACET, NS 3763 and topiramate) could not influence the course of the MS/EAE [4].

Evidence exists that activation of mGlu-I receptors enhances the function of NMDA receptors on neurons [70]. These receptors are also localized on ODC precursor cells, which play a beneficial role in maintaining glutathione levels and protect against oxidative stress. Thus these receptors have dual roles in the pathology of MS/EAE by damaging axons in lesional neurons and promoting remyelination by enlarging the viability of ODC precursors [4]. Because they are not expressed on mature ODCs, they cannot take part in primary glutamate excitotoxicity leading to cell death [4].

Glu has controversial impacts on CNS immune activity depending on which mGluRs exerts its effect. It can be immunosuppressive or increase the expression of proinflammatory cytokines. Glu can reduce the neurotoxicity of microglia via mGlu-III receptors or augment it through mGlu-II receptor activation and consecutive TNF- $\alpha$ release by activated microglia [8]. The immunomodulatory effects of mGlu-III receptors may be used to find novel therapies. Cinnabarinic acid, a partial agonist of mGlu4 (a group III metabotropic GluR) is protective in EAE. This agent is an endogenous metabolite of tryptophan (TRY) produced in the kynurenine pathway (KP) of TRY metabolism [4,71]. In addition, cinnabarinic acid influences neuroinflammation, by shifting T-cell differentiation towards the Th17 cell population, which are responsible for immune tolerance and may protect against EAE. Thus cinnabarinic acid is a link between the CNS and the immune system [71]. 
When Glu binds to its ionotropic receptors, high volumes of $\mathrm{Ca}^{2+}$ stream into the cell which leads to cell death via a cascade mechanism. Most of these processes are less known or hypothetical and include the production of free radicals, dysfunctions in mitochondrial operation and the activation of proapoptotic pathways. Excessive extracellular Glu generates overstimulation of Glu-receptors, which is the main factor for intracellular oxidative stress [4]. Beside $\mathrm{Ca}^{2+}, \mathrm{Na}^{+}$will overload the cells which open $\mathrm{Na}^{+} / \mathrm{Ca}^{2+}$ exchangers and voltage-gated $\mathrm{Ca}^{2+}$ channels resulting in more $\mathrm{Ca}^{2+}$ influx [27]. $\mathrm{Ca}^{2+}$-binding proteins could buffer the effect of excitotoxicity. Unfortunately ODCs do not express them, which makes the cells more susceptible to the impact of Glu [27]. Elevated $\mathrm{Ca}^{2+}$ levels provoke nitric-oxide (NO) production, activation of $\mathrm{Ca}^{2+}$-sensitive proteases and mitochondrial injury. Proapoptotic mechanisms activate proteases (caspases and calpains) [4]. Calpains induce DNA fragmentation. Their inhibitors protect neurons from NMDA-mediated excitotoxic injuries, curiously without incorporating normal receptor functions like learning or memory progresses, and may be examined as possible novel therapeutic agents in MS [4].

\subsection{The Role of Kynurenines in Glutamate Excitotoxicity in MS/EAE}

In the pathology of different neurodegenerative disorders, the metabolism of endogenous TRY to kynurenic acid (KYNA) and / or quinolinic acid (QUIN) has received intensified attention because of its dual behavior of being neuroprotective or neurotoxic [71-78]. The steps of TRY metabolism are shown in Figure 1.

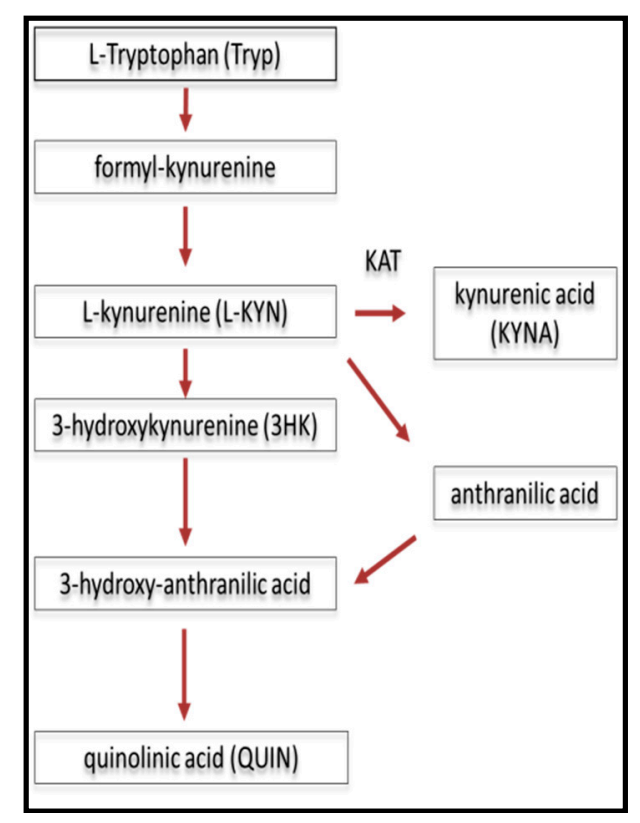

Figure 1. The metabolism of tryptophane: the kynurenine pathway. The red arrows show the direction of the metabolism. KAT: kynurenine-aminotranspherase (adapted from Bohár et al., 2015 [72]).

KYNA, which is an endogenous antagonist of iGluRs like NMDAR, has neuroprotective attributes. Low concentrations of KYNA facilitate AMPA receptors, while increased levels interfere with them $[71,77,79,80]$. It can inhibit presynaptic Glu release via $\alpha 7$-nicotinic-acetylcholine-receptors even at low concentrations, which makes it a potent neuroprotective agent [71]. KYNA expressed by astrocytes can counterbalance the neurotoxin-producing effect of the microglia at the site of local injury [81]. During the course of MS, KYNA levels change several times. It increases in the acute phase and later, with the progression of the disease, gradually decreases because of alterations in the KP. This effect indicates the possible neuroprotective role of KYNA in neurodegenerative processes [71]. 
Microglial cells produce and liberate the excitotoxin NMDA-agonist QUIN [81]. In EAE rodents and in MS patients pathologically high levels of this agent were demonstrated [82]. In opposition to KYNA, QUIN facilitates neurotoxic effects by raising extracellular Glu levels through inhibiting reuptake into astrocytes and releasing Glu from neurons. It is responsible for lipid peroxidation and oxidative stress too [71]. Increased local levels of QUIN are able to participate in demyelination in EAE and possibly MS [81]. Apoptosis of different kinds of CNS cells (ODCs, neurons, and astrocytes) can be mediated by QUIN exposure in EAE [83].

\subsection{Blood-Brain Barrier Dysfunction}

The function of the BBB is to maintain and protect the special micro-environment of the CNS by ensuring the intricate molecular interactions between neurons and glial cells. In the development of MS/EAE pathology, the evolution of BBB-dysfunction is fundamental and recent studies indicate that Glu has a significant role in this. Polymorphonuclear leukocytes in CNS circulation are able to release Glu by inflammatory processes, which induces a disruption of the BBB via mGluRs [84]. Through the compromised barrier further Glu molecules leak from the serum into the CNS, augmenting excitotoxicity [5]. NMDA and kainate receptors are expressed on cerebral endothelial cells inducing more BBB injury $[42,84]$. On the abluminal side, EAAT1, $-2,-3$ can be found which eliminate superabundant Glu from the extracellular space, thereby lowering the impact of excitotoxic damages [4].

\section{Mitochondrial Disturbances in EAE and MS}

Increasing evidence suggests that mitochondrial dysfunction plays an important role in the neurodegenerative processes, occurring most prominently in progressive MS. These processes involve mitochondrial DNA damage, abnormal mitochondrial gene expression, insufficient mitochondrial enzyme activity, and faulty DNA repair mechanisms [85].

Our current knowledge suggests that mitochondria are genetically independent organelles that can be found in every single eukaryotic cell, possessing their own DNA. They play a very important role in providing energy to cells by synthesizing adenosine triphosphate (ATP), moreover, they play a role in the metabolism of fatty acids and in programmed cell death (apoptosis) [86-89]. The mitochondrial respiratory chain can be found on the inner mitochondrial membrane, consisting of four complexes (complex I-IV), the fifth complex contributes directly to ATP synthesis $[87,88,90]$. These complexes are built of multiple subunits, most parts are proteins coded by mtDNA, and only complex II is encoded by nuclear DNA $[89,91]$. Neurons are highly dependent on oxidative energy metabolism. The greatest amount of ATP is produced during oxidative phosphorylation. In this process, large amounts of reactive oxygen and nitrogen species (ROS and RNS, respectively) are formed that are harmful to the cell. Production of cellular antioxidants serves as a countermeasure against this process [92,93]. This process stays in a highly sensitive balance. In the specific case when ROS and RNS synthesis exceeds antioxidant synthesis it results in oxidative stress and cell components are damaged in the cell $[90,91,94-97]$. Mitochondrial dysfunction results in a decrease in ATP synthesis, impaired $\mathrm{Ca}^{2+}$ content, and increased ROS and RNS at the same time [98]. Due to increased lipid peroxidation as a result of elevated ROS levels, membrane injuries occur, secondary failures accumulate in mitochondrial DNA (mtDNA) (as secondary de novo mutations). Aging is thought to be accelerated by mitochondrial genome alterations, and the decline of energy production, although ROS production increases further.

Mitochondrial damage in MS was found to play an important role in the progression of the disease [99-101]. The 3-step hypothesis describes a compensatory axonal response, pre-progression of mtDNA deletions, which is still a reversible phase, and finally an irreversible phase. Axonal transport deficits were discovered early in the disease course with focal axonal degeneration [102,103]. The axonal energy failure leads to synaptic atrophy, but not loss [104,105]. Using electron microscopy, significant damage among mitochondria and microtubuli was seen, furthermore, calcium-mediated damage could be verified, resulting in chronically demyelinated axons $[106,107]$. Cyclophylin D 
(CyPD), a regulator of the mitochondrial permeability transition pore (mPTP), plays an important role in cell death due to calcium mediation and oxidative stress [108,109]. Mice lacking CyPD were found to be more resistant to oxidative stress, and axonal degeneration also occurred at a lower rate [110]. Leber's hereditary optic neuropathy (LHON) is caused by mtDNA mutations, although other studies indicate that development of severe optic neuritis and mutations of mtDNA may have causal correlation [102,111-113]. Mitochondrial dysfunction was hypothesized to occur as a result of axonal degeneration in the white matter of MS lesions. Multiple studies have supported the same data [99]. In a recent study, acute mitochondrial damage was found in experimental inflammatory lesions in EAE, which resulted in focal axonal degeneration [102]. Similar changes have been found in post mortem MS lesions. A correlation between severity of inflammation and levels of ROS and RNS, produced by macrophages and microglia, has also been found in EAE and MS lesions [114,115]. It has been verified that following ROS detoxification by free radical scavengers, mitochondrial damage and focal axonal degeneration occurred at a lower rate [102]. Mitochondrial dysfunction was shown not only in WM lesions, but also in the gray matter. A comprehensive study verified a decline in activity of oxidative phosphorylation complexes I, III, and IV and deletions of mtDNA in non-myelinated post mortem motor cortex areas of MS patients $[106,116]$. Another study found multiple failures in several active MS lesions in complex IV protein of the mitochondrial respiratory chain [117]. An increase in the activity of complex IV proteins has been found in chronic inactive MS lesions [104]. Damaged mtDNA and decreased levels of OXPHOS complexes may be a consequence of oxidative and nitrosative stress $[116,118]$.

Recent findings seem to verify the hypothesis that MS is a 2-phase disease, in which inflammation dominates at the beginning, but neurodegeneration takes over later, although, the latter can also be found in the early stages of the disease. A new study found that mitochondrial damage can precede inflammation in EAE, suggesting that mitochondrial dysfunction is primary in the disease [119]. The process of neurodegeneration and mitochondrial disturbances in MS has not yet been clarified, but the combined effects of hypoxia, superoxide, and nitric oxide may play an important role in mitochondrial dysfunction [119]. Under experimental circumstances, it has been reported in EAE, that mitochondrial dysfunction can be found in the early stage of MS disease [120]. In a recent study (based on histological evidence), the excessive production of nitric oxide by activated microglia and macrophages can be a cause of reversible conduction block, which is observed in demyelinated axons $[121,122]$. In EAE, it has been found that nitric oxide, superoxide, and peroxinitrite can impair mitochondrial function, thereby inhibiting mitochondrial complexes I to $\mathrm{V}$, aconitase, manganese superoxide dismutase, and creatine kinase, which can lead to damage of mtDNA, lipidperoxidation and increased mitochondrial proton permeability [123-125].

\section{Redox Disturbances in EAE and MS}

Free radicals have a central role in several physiological and pathological processes. Both ROS and RNS originate from endogenous and exogenous sources. Mitochondria, endoplasmic reticulum, peroxisomes, phagocytic cells, and others serve as endogenous sources, and predominantly environmental factors, such as alcohol, tobacco, pollution, industrial solvents, pesticides, heavy metals, specified medicines, etc. make up the exogenous factors. Pathological conditions where free radicals are involved are diabetes, cardiovascular and respiratory diseases, cancers, Alzheimer's and Parkinson's disease, as well as MS. They are the product of normal cellular metabolism. Normally free radicals are involved in different physiological processes, like mitogenic response, cellular signaling pathways, redox regulation, and defense against pathogens. The molecular targets in oxidative and nitrosative stress are DNA, RNA, proteins, and lipids [126].

The CNS is particularly susceptible to damage because of its high oxygen requirement, high lipid content, and low levels of antioxidant enzymes. Antioxidants of enzymatic and nonenzymatic origin can be found in different parts of the cells (Table 6). 
Blood reduced glutathione (GSH) and oxidized glutathione (GSSG) levels are an index of whole body oxidative stress [127]. Both GSH and $\alpha$-tocopherol levels remain stable with aging [128]. The antioxidant enzyme superoxide dismutase (SOD) is present primarily in neurons, while GSH and glutathione peroxidase are in astrocytes [129]. In MS the source of ROS is proposed to be the activated microglia and macrophages, which induce lipid peroxidation as a key feature [130].

Table 6. Enzymatic and nonenzymatic antioxidants.

\begin{tabular}{|c|c|c|}
\hline Enzymatic Antioxidants & Source & Properties \\
\hline $\mathrm{Zn} / \mathrm{Cu}-\mathrm{SOD}$ & nucleus and cytosol & inhibitor of lipid peroxidation \\
\hline Mn-SOD & mitochondria & inhibitor of lipid peroxidation \\
\hline catalase & peroxisome & inhibitor of lipid peroxidation \\
\hline glutathione peroxidase & mitochondria & inhibitor of lipid peroxidation \\
\hline $\begin{array}{c}\text { glucose-6-phosphate } \\
\text { dehydrogenase }\end{array}$ & mitochondria & inhibitor of lipid peroxidation \\
\hline Nonenzymatic Antioxidants & Source & Properties \\
\hline$\alpha$-tocopherol & intravasal, cell membrane & $\begin{array}{l}\text { inhibitor of lipid peroxidation } \\
\text { hydrophobic scavenger inhibits the } \\
\text { propagation of the chain reaction }\end{array}$ \\
\hline carotenoids & intravasal, cell membrane & \\
\hline glutathione & intravasal, mitochondrial, nuclear & $\begin{array}{l}\text { inhibitor of lipid peroxidation } \\
\text { hydrophilic scavenger prevents the } \\
\text { initiation of radical formation }\end{array}$ \\
\hline ascorbic acid & intravasal & inhibitor of lipid peroxidation \\
\hline ceruloplasmin & intravasal & inhibitor of lipid peroxidation \\
\hline transferrin & intravasal & inhibitor of lipid peroxidation \\
\hline uric acid & intravasal & inhibitor of lipid peroxidation \\
\hline Retinol & intravasal & inhibitor of lipid peroxidation \\
\hline SH groups & intravasal & inhibitor of lipid peroxidation \\
\hline
\end{tabular}

In EAE, significantly increased NO production, elevated malondialdehyde (MDA) levels, and reduced GSH concentration and SOD activity were found in the brain mass [131]. In the spinal cord of EAE mice significantly decreased concentrations of GSH were detected, which points to the defective expression of GSH synthesizing enzymes. Beside this, impaired Nrf2 regulation was also found [132]. Treating EAE animals with $\alpha$-tocopherol resulted in both amelioration of disease activity and progression. $\alpha$-Tocopherol also proved to inhibit interferon- $\gamma$ production leading to a change in cytokine release favorably shifting the immune responses [133]. Biliverdin reductase improved the pathological and clinical signs of EAE, acting as a scavenger for bilirubin [134]. In the cuprizone animal model of MS, resveratrol promoted remyelination by increasing Olig1 expression, moreover improving balance and motor coordination, reversing cuprizone-induced demyelination and alleviating oxidative stress [135]. 3H-1,2-dithiole-3-thione, a compound found in vegetables, both delays disease onset and dramatically decreases disease severity in EAE [136].

In MS relapse, significantly increased GSSG levels were measured in the blood. Independent of the activity of the disease in MS patients, GSH levels were higher compared to controls. During exacerbation, elevated plasma-free SH groups, decreased levels of alpha-tocopherol and alpha-tocopherol/lipid ratio were found. Interferon-beta- $1 b$ therapy increased the level of alpha-tocopherol, but not the corrected lipid levels after two months of therapy [127]. After six months of interferon- $\beta$ therapy, the earlier decreased $\alpha$-tocopherol levels were normalized in the erythrocytes of MS patients, while the 
$\alpha$-tocopherol/lipid ratios remained constant [137]. This finding was supported by another study, where, besides the increased alpha tocopherol levels during interferon-beta treatment, reduced disease activity on MRI was described [138]. Acar and colleagues found elevated levels of MDA, SOD, oxidative stress index in RR MS compared to healthy controls, while decreased NO and total antioxidative status levels were found [139]. In line with these, other studies increased levels of total glutathione, GSH, GSSG/GSH ratio and SOD in MS patients were also found [140]. RR MS patients had high MDA and glutathione peroxidase concentrations [141]. Conversely, slightly reduced SOD was reported among MS patients with reduced protein sulfhydryl (SH) groups [142]. These changes suggest increased free radical production and consumption of the scavenger molecules during the active phase of the disease. In cerebellar gray matter of the brain of MS patients, upregulated SOD1 and SOD2 enzymes were found [143].

Plasma lipid peroxidation studies failed to relate oxidative stress with disease progression [144]. Mitoxantrone is an antineoplastic drug used in active secondary progressive MS. After mitoxantrone therapy, a significant increase in the lipid peroxidation marker MDA level was found together with a significant reduction in MnSOD, catalase (CAT), and glutathione peroxidase (GSH-Px) activities in the CSF. In the serum MDA concentration increased and MnSOD activity decreased, while $\mathrm{Cu} / \mathrm{ZnSOD}$ activity increased [145]. Brain GSH levels followed by MRI over 3-5 years of secondary progressive (SP) MS patients were lower compared to the control group and patients with progression had lower frontal GSH levels [146]. A 12 month long fish oil rich diet did not change the glutathione redox activity in MS patients [147].

Elevated CSF MDA and antioxidant activity was found in both MS and Guillain-Barre syndrome, while in the sera these values were significantly decreased [148]. LHON is a mitochondrial genetic disease that affects both the optic nerve and the retina. In patients with LHON and also in asymptomatic carriers decreased $\alpha$-tocopherol/lipid ratio was found in the plasma, pointing to elevated tocopherol consumption and free radical generation [149]. A combined and constant deficiency of the reducing systems was found in two compound triose phosphate isomerase-deficient brothers with markedly decreased alpha-tocopherol, carotenoid and GSH levels in the plasma and erythrocytes [150]. In these diseases, the changes in the redox systems were similar to the alterations observed in MS.

$\alpha$-Tocopherol modulates mitochondrial hydrogen peroxide formation in a dose dependent manner [151]. It is mainly regenerated from its phenoxycal radical by ubiquinol [152]. Decreased vitamin levels ( $\alpha$-tocopherol, ascorbic acid, $\beta$-carotene, and retinol) were found in the plasma of relapsing-remitting (RR) MS patients during relapse [153]. High dose vitamin consumption elevated the initially low levels of glutathione peroxidase enzyme activity of MS patients after five weeks [154]. In a heterogeneous MS group of 170 patients (consisting of mainly RR MS patients), increased levels of plasma uric acid, oxypurins, MDA, nitrite, nitrate levels, while decreased ascorbic acid levels were found [155].

\section{Biomarkers in Tissue Damage of MS}

There are currently no diagnostics sensitive and specific enough for this disorder, the diagnosis relies more on clinical features. Thus, emerging research is trending toward CSF biomarkers, which could provide more specific data reflecting the heterogeneity of MS [156]. A biomarker is "a characteristic that is objectively measured and evaluated as an indicator of normal biological processes, pathogenic processes or pharmacological responses to a therapeutic intervention" [157]. It is a good supplementary marker "that is intended to substitute for a clinical endpoint" [157]. They may be used not only to diagnose the disease more specifically, but also to predict its course and facilitate personalized therapy by examining treatment response or detecting an increased possibility of severe side effects [156]. With the specificity of biomarkers it would be possible to differentiate between various disorder appearances or other demyelinating diseases resembling MS [158]. Besides CSF samples, there is a great attempt to find less invasive methods too. The plasma, urine, and saliva of MS patients are being researched using MR spectroscopy techniques. The biomolecules which may be putative biomarkers reflect the different 
CNS mechanisms like immunological changes or degenerative alterations in the progression of MS. Thus excitotoxins and redox system molecules could serve as biomarkers. Their detailed discussion is beyond the framework of this review, we want only to highlight some important aspects about them.

In the active phase of the disease, glutamate levels increase in patients' CSF as was shown in the above mentioned study by Sarchielli et al. The concentration of CSF Glu rose when the number of active demyelinating lesions increased in RRMS subjects [24]. With multivoxel magnetic resonance spectroscopy, Azevedo et al. found that in white matter with a normal appearance, elevated Glu levels and decreased $N$-acetyl-aspartate concentration (NAA) could predict disease progression [159]. MacMillan et al. found early and consistent alterations in the Glu and glutamine levels in CNS over two years in SPMS patients with MR spectroscopy. This method might be competent to measure disease progression over years, using the appropriate imaging techniques suggested by the authors [160].

Lately a great variety of oxidative stress enzymes, proteins, nucleic acids etc. have been examined in order to find new biomarkers. Some of these molecules are thiobarbituric acid reactive substances, advanced oxidation protein products, fructosamine [161], activated $\alpha$-2-macroglobulin [162], MDA, ceramides [163], chemokine 11 (CCL11) [164], the total level of advanced protein oxidation (AOPP), and a decreased level of total thiol groups [165].

The concentration alterations of molecules participating in oxidative stress mechanisms could predict the degree of disability or disease progression. One of the studies showed that serum levels of TNF- $\alpha$, IFN- $\gamma$, IL-4, IL-6, IL-10, and IL-17, albumin, ferritin, and plasma levels of AOPPs, NOx, and TRAP among others, might signal high disability measured by EDSS and are associated with different types of symptoms (pyramidal, sensory or cerebellar) [166].

Thiobarbituric acid reactive substances and advanced glycation end-products were found to be increased in the saliva of MS patients during relapses. This study showed higher levels of other oxidative stress biomarkers such as thiobarbituric acid reactive substances, advanced oxidation protein products, and fructosamine in plasma during relapses [161].

Isoprostanes (IsoP) - prostaglandin-like molecules originating from free radical-catalyzed peroxidation of essential fatty acids-reflect oxidative stress in different neurological disorders including MS. In RRMS it is supposed to be a marker of neurodegeneration with axonal injury, in which oxidative stress is involved [167]. A recent study measured this marker in patients experiencing the first clinical attack suggestive of MS, where increased levels of IsoP in CSF indicated the presence of oxidative stress in the very early course of the disease. This finding strengthens the theory that neurodegeneration occurs at the early onset of the disease [167]. Teunissen et al. found decreased IsoP serum concentration compared with CIS [168].

According to a study, decreased vitamin D-levels might be responsible for the development of MS [169]. Vitamin D-binding protein (DBP) was shown to be more oxidized in remitting and relapsing phases but with increased oxidation rates during relapses. The higher oxidation rate of DBP in remission indicates that some molecular processes are active and not perfectly inhibited in remission [170]. The oxidation of apolipoprotein A-IV increased with the progression of the disease [170].

In one pilot study, consecutive CSF samples from a fulminant MS case were examined. Seven proteins among seventy-eight biomarkers were detected to be elevated in RRMS patients as compared to heathy controls. They were responsible for immune response, blood coagulation, cell proliferation, and adhesion [171]. Further studies are needed to investigate this question with higher case numbers. The use of samples from biobanks could be a possibility to gather data about rare variants.

Despite the remarkable quantity of research in biomarker investigation only a few agents have been precisely validated and utilized in clinical practice [156]. There are difficulties in conferring the results because of differences in research methods, sample collection, and processing, as well as problems in storage and gathering data from published research. These lead to turmoil and hinder validation and efforts at putting biomarkers into use. To solve these problems, BioMS-eu (available on: http:/ /www.bioms.eu) network made a "consensus protocol for the standardization of cerebrospinal 
fluid collection and biobanking" in 2009 with an update in 2011 [172], for the purpose of standardizing sample collection, elaboration, storage, data acquisition, and processing, together with general database postulation. Obtaining more data and increasing the value of smaller investigations are expected with the use of these guidelines [172].

\section{Therapeutic Trials}

Despite the newest efficient immunomodulatory therapies, the complexity of MS and lack of further treatment effectiveness have turned attention to the examination of novel therapeutic opportunities. The fundamental and general participation of Glu in ODC death, axon damage, and BBB-dysfunction provides a promising target. Glutamate excitotoxicity is a common pathological reaction for different noxa attacking CNS cells [5], so experimental drugs hold hope for treating not only MS but other severe neurodegenerative disorders like ALS, Alzheimer's or stroke [73,75,77,78]. In EAE, a great variety of drugs connected to Glu metabolism have been tested. The different targets and drugs are shown in Figure 2.

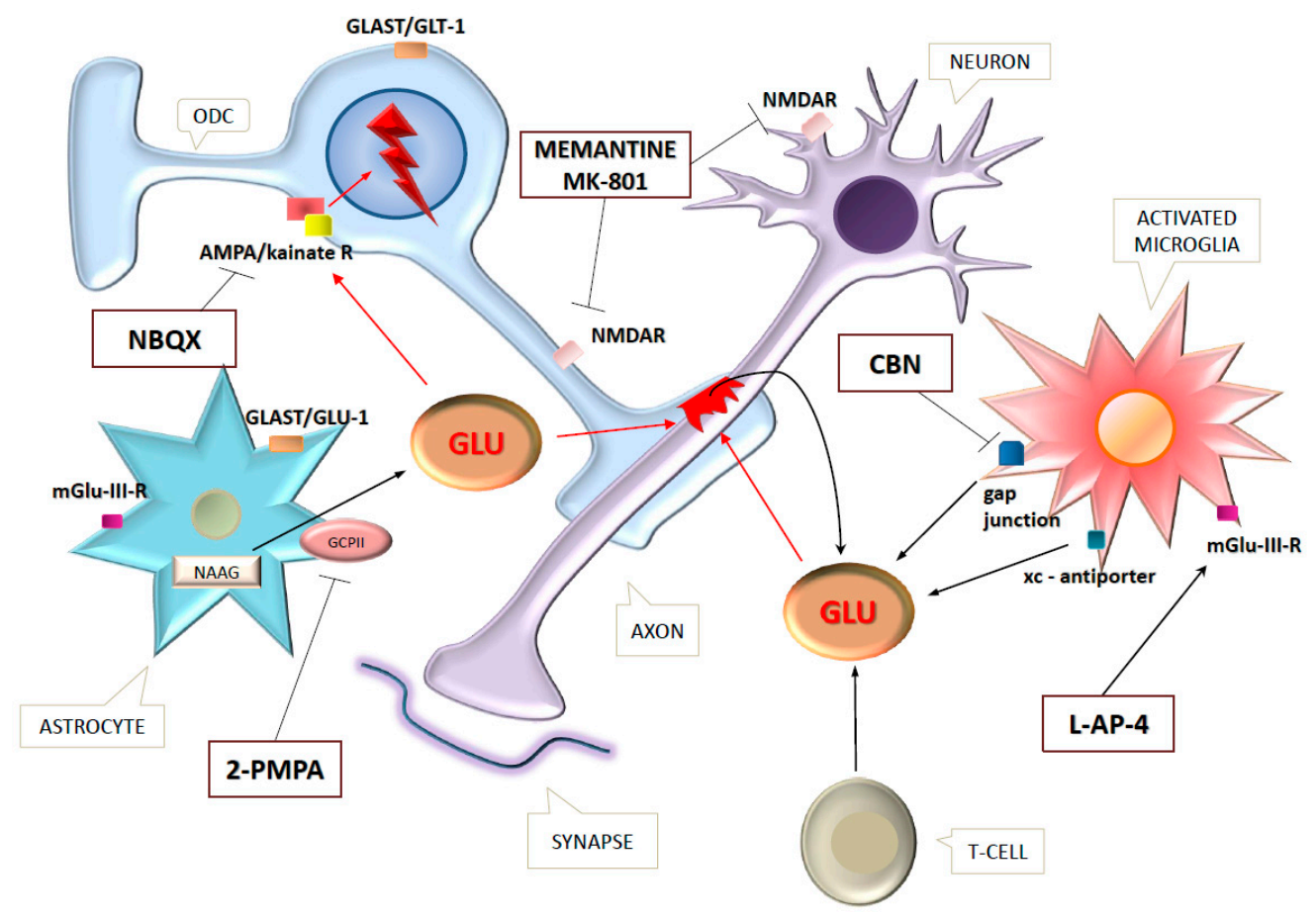

Figure 2. Therapeutic agents and their target points in EAE. The red frames show the site of the damage, the red arrows the route of excitotoxicity, black arrows indicate the direction of a reaction, and $\mathrm{T}$ sign mean blockade. Abbreviation: ODC: oligodendrocyte; R: receptor; GLU: glutamate; mGluIII-R: metabotropic glutamate-receptor; NMDAR: N-methyl-D-aspartate receptor; GLAST: glutamate-aspartate transporter, in human it is called EAAT1 (excitatory amino acid transporter-1); GLT-1: glial transporter-1, in human it is EAAT2; AMPA: $\alpha$-amino-3-hydroxy-5-methyl-4-isoxazolepropionicacide; $x c$-antiporter: system $\mathrm{x}_{\mathrm{c}}{ }^{-}$ cystin/glutamate antiporter; GCPII: Glutamate carboxipeptidase II; NAAG: -acetylaspartylglutamate; CNS: central nervous system.

One of the promising agents is matrine which is a natural alkaloid component of the Radix Sophorae Flaves, formerly used to treat hepatitis-B. It has anti-inflammatory effects and protects against demyelination. In EAE the use of matrine, resulted in Glu downregulation, EAAT overexpression, and decrease in NMDA/AMPA-levels [173].

Ha et al. (2016) [29] examined the impact of an efficient GCPII inhibitor, 2-phosphonomethyl pentanedioic acid (2-PMPA), on EAE mice and detected improvement in disease course and 
significantly decreased amounts of inflammatory cells infiltrating the CNS. This agent impeded the expression of mGluR1 in CNS and periphery too. Carbenoxolone, a microglia gap junction-blocker prevented neuronal cell death in a dosage-dependent manner and reduced the clinical symptoms of EAE [174].

The inflammatory and excitatory mechanisms which develop simultaneously provide dual targets for treatment. Kanwar et al. (2004) used anti-inflammatory (anti-MAdCAM-1: mucosal addressin cell adhesion molecule-1 monoclonal antibody) and neuroprotective (NBQX: AMPA-antagonist and /or GPE: N-terminal tripeptide of insulin-like growth factor) drugs in combination and found a decrease in clinical symptoms, along with remyelination and ODC viability advancement [175].

There are attempts to use KYNA analogues to treat neurodegenerative disorders [72,76,176-180]. The structural KYNA analogue quinoline carboxamide (laquinimod) slowed the progression of MS and the annual relapse rate in a phase 3 study [71]. Laquinimod may cross the BBB which is an important aspect of this treatment as the endogenous metabolite KYNA does not have this ability. It has great effects on immunoregulation by reducing antigen presentation and offsetting the immune response from Th1 to Th2, amongst others [71].

Luchtman et al. (2016) investigated the effects of immunomodulatory drugs on excitotoxicity in vitro. They found protective impacts of fumarates. Monomethyl-fumarate inhibited Glu release from Th17 cells too [181]. L-2-amino-4-phosphonobutanoate (L-AP-4), a specific agonist of mGluR III, enhanced the amelioration of EAE in Lewis rats [182].

However, the great outcomes seen in animal experiments (disease amelioration, decreased ODC death, and reduced axon injury) could not be observed in human research. i.e., memantine showed promising disease-modifying effects in EAE but its human trial was suspended because of disease progress $[30,183]$. The reason for this difference is unknown and needs to be investigated. The results of animal models and cell cultures can only be reported with caution, indicating the need for perfecting our own models.

Contrary to other neurodegenerative diseases, changes in mitochondrial function could be discovered early in the disease course of MS. Early consequences of synaptic dysfunction are motor and synaptic fatigability, while late consequences are synaptic loss. Evaluation of the reversible phenotype of patients by distinguishing them from the irreversible helps in identifying relevant patients groups with a therapeutic window for intervention.

Currently we lack medicine that could decrease or completely stop mitochondrial destruction and neurodegeneration. Possible therapeutic approaches target different parts of the mitochondrion (electron transport chain, ATP synthase, ROS). Some promising results from animal models shed light on different molecules. In experimental situations, insertion of superoxide dismutase 2 gene (SOD-2) neutralizes the superoxides, thereby stabilizing the integrity of the axon [184]. Knockout CyPD and p66ShcA significantly decreased axonal damage in EAE [110,185]. Currently two studies have described the defensive property of MitoQ, a synthetic antioxidant, in EAE. MitoQ did not affect inflammation, but decreased the extension of axonal damage [186,187]. Molecules increasing PGC-1a activity have extended neuronal survival in animal models [186-190]. In a recently published study, the molecule brain-derived neurotrophic factor (BDNF), originating from the CNS, may mediate axonal defense in EAE [191,192]. Two studies showed the increased secretion of BDNF as an effect in alemtuzumab and laquinimod intake [193,194]. In EAE, fumaric acid ester that is widely utilized in therapy of psoriasis, may yield neuroprotective effects [195,196]. Two molecules, dimethyl-fumarate and its primary metabolite, monomethyl-fumarate, have been found to increase cellular redox potential, glutathione and ATP levels, along with mitochondrial membrane potential. Thus, along the Nrf2 route those neurons were protected from damaging effects of astrocytes [197]. Nrf2 activates different antioxidants leading to a decrease in neurodegeneration [198].

Talla et al. recently decreased mitochondrial oxidative stress and apoptosis in EAE retina with an intravitreal injection of self-complementary adeno-associated virus containing the $\mathrm{NADH}$-dehydrogenase type-2 complex I gene as gene therapy, and managed to decrease axonal loss in the optic neuron [199]. 
Sirtuins SIRT-3 through SIRT-5 were identified as possible potent neuroprotective factors in demyelinating diseases. In one study Rice et al. found that sirtuins may carry a defensive effect against oxidative stress and excitotoxicity [200].

During the tricarboxylic acid (TCA or Krebs) cycle a significant amount of superoxide species is produced, which enhances neurodegeneration even further. According to several studies, a ketogenic diet helps to maintain ATP levels (by replacing intermediates of the TCA cycle) in the dysfunctional mitochondrial respiratory chain [90,95]. A study describes that beta-hydroxybutyrate attenuates decreased ATP production due to the failure of complex I, thus decreasing neurodegeneration in MS [201]. Biotin is essential for free fatty acid synthesis and energy production. A recently published study showed the daily intake of $300 \mathrm{mg}$-s of biotine decreased the severity of disability in MS by enhancing axonal remyelinisation [202]. Pyrimidine and its derivatives play an important role in the immune system (cellular adhesion and proliferation etc.). The need for pyrimidine in activated and proliferating lymphocytes is increased in MS, thus, the level of dihydroorotate dehydrogenase (DHODH)-dependent de novo pyrimidine synthesis increases simultaneously. Teriflunomide inhibits DHODH and as such, suppresses the JAK-STAT mediated synthesis and the secretion of proinflammatory cytokines (IL-17 and TNF) [203].

Key elements of therapeutic intervention could be Nrf2, DHODH and the TCA cycle.

While searching for antioxidant therapies, vitamin A and E have thus far been the most promising candidates as modulators in MS for future studies [204]. Modern research made it possible to quantify GABA, GSH, and glutamate together with other metabolites relevant in MS at 7T with high accuracy and reproducibility in a single 1-h session [205]. This technique helps profile the metabolic changes during the disease course to identify potentially relevant targets.

\section{Conclusions}

Glutamate excitotoxicity, mitochondrial dysfunction, and redox disturbances are key features in the pathogenesis of MS. Mitochondrial disturbances, neuroinflammation, and increased oxidative stress are closely related processes which show a correlation with axonal degeneration in MS lesions. The CNS is particularly susceptible to oxidative and nitrosative stress. Among possible antioxidants, vitamin $\mathrm{A}$ and $\mathrm{E}$ are at present the most promising candidates. Glutamate excitotoxicity can be attributed to an increased Glu release, a deficit in Glu reuptake, and altered function of the enzymes participating in Glu metabolism or glutamate receptors. Kynurenines may influence glutamatergic processes, among these, KYNA might act as a neuroprotective molecule by counteracting glutamate excitotoxicity. The identification of potential novel candidates which may prevent oxidative stress, mitochondrial disturbances or excitotoxicity stands in the focus of research. Another main aim of investigations is the identification of biomarkers for MS, which may promote not only the early diagnosis but also the development of personalized therapy.

Acknowledgments: This work was supported by the MTA-SZTE Neuroscience Research Group of the Hungarian Academy of Sciences and the University of Szeged, the Hungarian Brain Research Program (NAP, Grant No. KTIA-13-NAP-A-II/18) and GINOP-2.3.2-15-2016-00034. We wish to thank Jennifer Tusz for editing the English of this manuscript.

Author Contributions: Cecilia Rajda, Dániel Pukoli, Zsuzsanna Bende contributed to the writing of the article, Zsófia Majláth and László Vécsei revised the manuscript.

Conflicts of Interest: The authors declare no conflict of interest.

\section{Abbreviations}

AMPA $\quad \alpha$-amino-3-hydroxy-5-methyl-4-isoxazolepropionic acid

AMPAR $\quad \alpha$-amino-3-hydroxy-5-methyl-4-isoxazolepropionic acid receptor

ATP adenosine triphosphate 


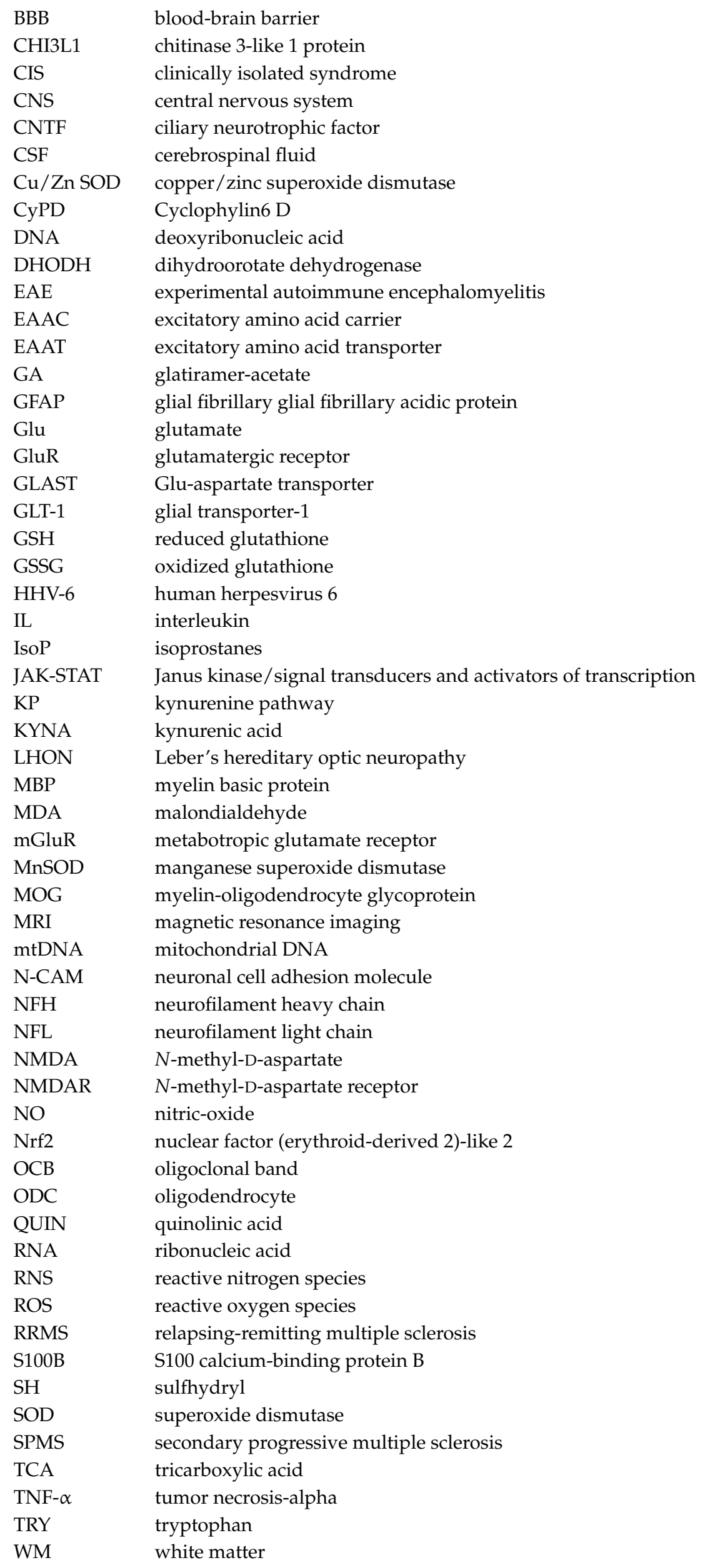




\section{References}

1. Peterson, L.K.; Fujinami, R.S. Inflammation, demyelination, neurodegeneration and neuroprotection in the pathogenesis of multiple sclerosis. J. Neuroimmunol. 2007, 184, 37-44. [CrossRef] [PubMed]

2. Frischer, J.M.; Bramow, S.; Dal-Bianco, A.; Lucchinetti, C.F.; Rauschka, H.; Schmidbauer, M.; Laursen, H.; Sorensen, P.S.; Lassmann, H. The relation between inflammation and neurodegeneration in multiple sclerosis brains. Brain 2009, 132, 1175-1189. [CrossRef] [PubMed]

3. Stys, P.K.; Zamponi, G.W.; van Minnen, J.; Geurts, J.J. Will the real multiple sclerosis please stand up? Nat. Rev. Neurosci. 2012, 13, 507-514. [CrossRef] [PubMed]

4. Kostic, M.; Zivkovic, N.; Stojanovic, I. Multiple sclerosis and glutamate excitotoxicity. Rev. Neurosci. 2013, 24, 71-88. [CrossRef] [PubMed]

5. Stojanovic, I.R.; Kostic, M.; Ljubisavljevic, S. The role of glutamate and its receptors in multiple sclerosis. J. Neural Transm. 2014, 121, 945-955. [CrossRef] [PubMed]

6. Werner, P.; Pitt, D.; Raine, C.S. Multiple sclerosis: Altered glutamate homeostasis in lesions correlates with oligodendrocyte and axonal damage. Ann. Neurol. 2001, 50, 169-180. [CrossRef] [PubMed]

7. Popescu, B.F.; Pirko, I.; Lucchinetti, C.F. Pathology of multiple sclerosis: Where do we stand? Continuum 2013, 19, 901-921. [CrossRef] [PubMed]

8. Prins, M.; Schul, E.; Geurts, J.; van der Valk, P.; Drukarch, B.; van Dam, A.M. Pathological differences between white and grey matter multiple sclerosis lesions. Ann. N. Y. Acad. Sci. 2015, 1351, 99-113. [CrossRef] [PubMed]

9. Calabrese, M.; Magliozzi, R.; Ciccarelli, O.; Geurts, J.J.; Reynolds, R.; Martin, R. Exploring the origins of grey matter damage in multiple sclerosis. Nat. Rev. Neurosci. 2015, 16, 147-158. [CrossRef] [PubMed]

10. Benedict, R.H.; Ramasamy, D.; Munschauer, F.; Weinstock-Guttman, B.; Zivadinov, R. Memory impairment in multiple sclerosis: Correlation with deep grey matter and mesial temporal atrophy. J. Neurol. Neurosurg. Psychiatry 2009, 80, 201-206. [CrossRef] [PubMed]

11. Peterson, J.W.; Bö, L.; Mörk, S.; Chang, A.; Trapp, B.D. Transected neurites, apoptotic neurons, and reduced inflammation in cortical multiple sclerosis lesions. Ann. Neurol. 2001, 50, 389-400. [CrossRef] [PubMed]

12. Brink, B.P.; Veerhuis, R.; Breij, E.C.; van der Valk, P.; Dijkstra, C.D.; Bö, L. The pathology of multiple sclerosis is location-dependent: No significant complement activation is detected in purely cortical lesions. J. Neuropathol. Exp. Neurol. 2005, 64, 147-155. [CrossRef] [PubMed]

13. Van Horssen, J.; Brink, B.P.; de Vries, H.E.; van der Valk, P.; Bø, L. The blood-brain barrier in cortical multiple sclerosis lesions. J. Neuropathol. Exp. Neurol. 2007, 66, 321-328. [CrossRef] [PubMed]

14. Centonze, D.; Muzio, L.; Rossi, S.; Cavasinni, F.; de Chiara, V.; Bergami, A.; Musella, A.; D'Amelio, M.; Cavallucci, V.; Martorana, A.; et al. Inflammation triggers synaptic alteration and degeneration in experimental autoimmune encephalomyelitis. J. Neurosci. 2009, 29, 3442-3452. [CrossRef] [PubMed]

15. Friese, M.A.; Schattling, B.; Fugger, L. Mechanisms of neurodegeneration and axonal dysfunction in multiple sclerosis. Nat. Rev. Neurol. 2014, 10, 225-238. [CrossRef] [PubMed]

16. Danbolt, N.C. Glutamate uptake. Prog. Neurobiol. 2001, 65, 1-105. [CrossRef]

17. Yudkoff, M.; Daikhin, Y.; Nissim, I. Acidosis and astrocyte amino acid metabolism. Neurochem. Int. 2000, 36, 329-339. [CrossRef]

18. Daikhin, Y.; Yudkoff, M. Compartmentation of brain glutamate metabolism in neurons and glia. J. Nutr. 2000, 130, 1026S-1031S. [PubMed]

19. Tansey, F.A.; Farooq, M.; Cammer, W. Glutamine synthetase in oligodendrocytes and astrocytes: New biochemical and immunocytochemical evidence. J. Neurochem. 1991, 56, 266-272. [CrossRef] [PubMed]

20. Pitt, D.; Nagelmeier, I.E.; Wilson, H.C.; Raine, C.S. Glutamate uptake by oligodendrocytes: Implications for excitotoxicity in multiple sclerosis. Neurology 2003, 61, 1113-1120. [CrossRef] [PubMed]

21. Thomas, A.G.; O’Driscoll, C.M.; Bressler, J.; Kaufmann, W.; Rojas, C.J.; Slusher, B.S. Small molecule glutaminase inhibitors block glutamate release from stimulated microglia. Biochem. Biophys. Res. Commun. 2014, 443, 32-36. [CrossRef] [PubMed]

22. Olney, J.W.; Sharpe, L.G. Brain lesions in an infant rhesus monkey treated with monsodium glutamate. Science 1969, 166, 386-388. [CrossRef] [PubMed] 
23. Stover, J.F.; Pleines, U.E.; Morganti-Kossmann, M.C.; Kossmann, T.; Lowitzsch, K.; Kempski, O.S. Neurotransmitters in cerebrospinal fluid reflect pathological activity. Eur. J. Clin. Investig. 1997, 27, 1038-1043. [CrossRef]

24. Sarchielli, P.; Greco, L.; Floridi, A.; Gallai, V. Excitatory amino acids and multiple sclerosis: Evidence from cerebrospinal fluid. Arch. Neurol. 2003, 60, 1082-1088. [CrossRef] [PubMed]

25. Srinivasan, R.; Sailasuta, N.; Hurd, R.; Nelson, S.; Pelletier, D. Evidence of elevated glutamate in multiple sclerosis using magnetic resonance spectroscopy at 3 T. Brain 2005, 128, 1016-1025. [CrossRef] [PubMed]

26. Cianfoni, A.; Niku, S.; Imbesi, S.G. Metabolite findings in tumefactive demyelinating lesions utilizing short echo time proton magnetic resonance spectroscopy. AJNR Am. J. Neuroradiol. 2007, 28, 272-277. [PubMed]

27. Matute, C.; Alberdi, E.; Domercq, M.; Pérez-Cerdá, F.; Pérez-Samartín, A.; Sánchez-Gómez, M.V. The link between excitotoxic oligodendroglial death and demyelinating diseases. Trends Neurosci. 2001, 24, 224-230. [CrossRef]

28. Pitt, D.; Werner, P.; Raine, C.S. Glutamate excitotoxicity in a model of multiple sclerosis. Nat. Med. 2000, 6, 67-70. [CrossRef] [PubMed]

29. Ha, D.; Bing, S.J.; Ahn, G.; Kim, J.; Cho, J.; Kim, A.; Herath, K.; Yu, H.S.; Jo, S.A.; Cho, I.H.; et al. Blocking glutamate carboxypeptidase II inhibits glutamate excitotoxicity and regulates immune responses in experimental autoimmune encephalomyelitis. FEBS J. 2016, 283, 3438-3456. [CrossRef] [PubMed]

30. Paul, C.; Bolton, C. Modulation of blood-brain barrier dysfunction and neurological deficits during acute experimental allergic encephalomyelitis by the $N$-methyl-D-aspartate receptor antagonist memantine. J. Pharmacol. Exp. Ther. 2002, 302, 50-57. [CrossRef] [PubMed]

31. Smith, T.; Groom, A.; Zhu, B.; Turski, L. Autoimmune encephalomyelitis ameliorated by AMPA antagonists. Nat. Med. 2000, 6, 62-66. [CrossRef] [PubMed]

32. Geurts, J.J.; Barkhof, F. Grey matter pathology in multiple sclerosis. Lancet Neurol. 2008, 7, 841-851. [CrossRef]

33. Olney, J.W. Glutamate, a neurotoxic transmitter. J. Child. Neurol 1989, 4, 218-226. [CrossRef] [PubMed]

34. Mandolesi, G.; Gentile, A.; Musella, A.; Fresegna, D.; de Vito, F.; Bullitta, S.; Sepman, H.; Marfia, G.A.; Centonze, D. Synaptopathy connects inflammation and neurodegeneration in multiple sclerosis. Nat. Rev. Neurol. 2015, 11, 711-724. [CrossRef] [PubMed]

35. Piani, D.; Frei, K.; Do, K.Q.; Cuénod, M.; Fontana, A. Murine brain macrophages induced nmda receptor mediated neurotoxicity in vitro by secreting glutamate. Neurosci. Lett. 1991, 133, 159-162. [CrossRef]

36. Yawata, I.; Takeuchi, H.; Doi, Y.; Liang, J.; Mizuno, T.; Suzumura, A. Macrophage-induced neurotoxicity is mediated by glutamate and attenuated by glutaminase inhibitors and gap junction inhibitors. Life Sci. 2008, 82, 1111-1116. [CrossRef] [PubMed]

37. Piani, D.; Fontana, A. Involvement of the cystine transport system $\mathrm{x}_{\mathrm{c}}{ }^{-}$in the macrophage-induced glutamate-dependent cytotoxicity to neurons. J. Immunol. 1994, 152, 3578-3585. [PubMed]

38. Pampliega, O.; Domercq, M.; Soria, F.N.; Villoslada, P.; Rodríguez-Antigüedad, A.; Matute, C. Increased expression of cystine/glutamate antiporter in multiple sclerosis. J. Neuroinflamm. 2011, 8, 63. [CrossRef] [PubMed]

39. Bezzi, P.; Carmignoto, G.; Pasti, L.; Vesce, S.; Rossi, D.; Rizzini, B.L.; Pozzan, T.; Volterra, A. Prostaglandins stimulate calcium-dependent glutamate release in astrocytes. Nature 1998, 391, 281-285. [PubMed]

40. Bezzi, P.; Domercq, M.; Brambilla, L.; Galli, R.; Schols, D.; de Clercq, E.; Vescovi, A.; Bagetta, G.; Kollias, G.; Meldolesi, J.; et al. CXCR4-activated astrocyte glutamate release via TNF $\alpha$ : Amplification by microglia triggers neurotoxicity. Nat. Neurosci. 2001, 4, 702-710. [CrossRef] [PubMed]

41. Kukley, M.; Capetillo-Zarate, E.; Dietrich, D. Vesicular glutamate release from axons in white matter. Nat. Neurosci. 2007, 10, 311-320. [CrossRef] [PubMed]

42. Newcombe, J.; Uddin, A.; Dove, R.; Patel, B.; Turski, L.; Nishizawa, Y.; Smith, T. Glutamate receptor expression in multiple sclerosis lesions. Brain Pathol. 2008, 18, 52-61. [CrossRef] [PubMed]

43. Sriram, S.; Rodriguez, M. Indictment of the microglia as the villain in multiple sclerosis. Neurology 1997, 48, 464-470. [CrossRef] [PubMed]

44. Martinez-Hernandez, A.; Bell, K.P.; Norenberg, M.D. Glutamine synthetase: Glial localization in brain. Science 1977, 195, 1356-1358. [CrossRef] [PubMed]

45. Oka, A.; Belliveau, M.J.; Rosenberg, P.A.; Volpe, J.J. Vulnerability of oligodendroglia to glutamate: Pharmacology, mechanisms, and prevention. J. Neurosci. 1993, 13, 1441-1453. [PubMed] 
46. Olmos, G.; Lladó, J. Tumor necrosis factor $\alpha$ : A link between neuroinflammation and excitotoxicity. Mediat. Inflamm. 2014, 2014, 861231. [CrossRef] [PubMed]

47. Korn, T.; Magnus, T.; Jung, S. Autoantigen specific T cells inhibit glutamate uptake in astrocytes by decreasing expression of astrocytic glutamate transporter GLAST: A mechanism mediated by tumor necrosis factor- $\alpha$. FASEB J. 2005, 19, 1878-1880. [CrossRef] [PubMed]

48. Ye, L.; Huang, Y.; Zhao, L.; Li, Y.; Sun, L.; Zhou, Y.; Qian, G.; Zheng, J.C. Il-1 $\beta$ and TNF- $\alpha$ induce neurotoxicity through glutamate production: A potential role for neuronal glutaminase. J. Neurochem. 2013, 125, 897-908. [CrossRef] [PubMed]

49. Vesce, S.; Rossi, D.; Brambilla, L.; Volterra, A. Glutamate release from astrocytes in physiological conditions and in neurodegenerative disorders characterized by neuroinflammation. Int. Rev. Neurobiol. 2007, 82, 57-71. [PubMed]

50. Stys, P.K.; Waxman, S.G.; Ransom, B.R. Ionic mechanisms of anoxic injury in mammalian cns white matter: Role of $\mathrm{Na}^{+}$channels and $\mathrm{Na}^{+}-\mathrm{Ca}^{2+}$ exchanger. J. Neurosci. 1992, 12, 430-439. [PubMed]

51. Sulkowski, G.; Dąbrowska-Bouta, B.; Salińska, E.; Strużyńska, L. Modulation of glutamate transport and receptor binding by glutamate receptor antagonists in EAE rat brain. PLoS ONE 2014, 9, e113954. [CrossRef] [PubMed]

52. Domercq, M.; Etxebarria, E.; Pérez-Samartín, A.; Matute, C. Excitotoxic oligodendrocyte death and axonal damage induced by glutamate transporter inhibition. Glia 2005, 52, 36-46. [CrossRef] [PubMed]

53. Vallejo-Illarramendi, A.; Domercq, M.; Pérez-Cerdá, F.; Ravid, R.; Matute, C. Increased expression and function of glutamate transporters in multiple sclerosis. Neurobiol. Dis. 2006, 21, 154-164. [CrossRef] [PubMed]

54. Mitosek-Szewczyk, K.; Sulkowski, G.; Stelmasiak, Z.; Struzyńska, L. Expression of glutamate transporters GLT-1 and GLAST in different regions of rat brain during the course of experimental autoimmune encephalomyelitis. Neuroscience 2008, 155, 45-52. [CrossRef] [PubMed]

55. De Silva, T.M.; Kabakov, A.Y.; Goldhoff, P.E.; Volpe, J.J.; Rosenberg, P.A. Regulation of glutamate transport in developing rat oligodendrocytes. J. Neurosci. 2009, 29, 7898-7908. [CrossRef] [PubMed]

56. Geurts, J.J.; Wolswijk, G.; Bö, L.; van der Valk, P.; Polman, C.H.; Troost, D.; Aronica, E. Altered expression patterns of group I and II metabotropic glutamate receptors in multiple sclerosis. Brain 2003, 126, 1755-1766. [CrossRef] [PubMed]

57. Han, M.H.; Hwang, S.I.; Roy, D.B.; Lundgren, D.H.; Price, J.V.; Ousman, S.S.; Fernald, G.H.; Gerlitz, B.; Robinson, W.H.; Baranzini, S.E.; et al. Proteomic analysis of active multiple sclerosis lesions reveals therapeutic targets. Nature 2008, 451, 1076-1081. [CrossRef] [PubMed]

58. Zhai, D.; Lee, F.H.; D'Souza, C.; Su, P.; Zhang, S.; Jia, Z.; Zhang, L.; Wong, A.H.; Liu, F. Blocking GluR2-GAPDH ameliorates experimental autoimmune encephalomyelitis. Ann. Clin. Transl. Neurol. 2015, 2, 388-400. [CrossRef] [PubMed]

59. Dingledine, R.; Borges, K.; Bowie, D.; Traynelis, S.F. The glutamate receptor ion channels. Pharmacol. Rev. 1999, 51, 7-61. [PubMed]

60. Káradóttir, R.; Cavelier, P.; Bergersen, L.H.; Attwell, D. NMDA receptors are expressed in oligodendrocytes and activated in ischaemia. Nature 2005, 438, 1162-1166. [CrossRef] [PubMed]

61. Livesey, M.R.; Magnani, D.; Cleary, E.M.; Vasistha, N.A.; James, O.T.; Selvaraj, B.T.; Burr, K.; Story, D.; Shaw, C.E.; Kind, P.C.; et al. Maturation and electrophysiological properties of human pluripotent stem cell-derived oligodendrocytes. Stem Cells 2016, 34, 1040-1053. [CrossRef] [PubMed]

62. Matute, C.; Sánchez-Gómez, M.V.; Martínez-Millán, L.; Miledi, R. Glutamate receptor-mediated toxicity in optic nerve oligodendrocytes. Proc. Natl. Acad. Sci. USA 1997, 94, 8830-8835. [CrossRef] [PubMed]

63. Werner, P.; Pitt, D.; Raine, C.S. Glutamate excitotoxicity-A mechanism for axonal damage and oligodendrocyte death in multiple sclerosis? J. Neural Transm. Suppl. 2000, 60, 375-385.

64. Ouardouz, M.; Coderre, E.; Zamponi, G.W.; Hameed, S.; Yin, X.; Trapp, B.D.; Stys, P.K. Glutamate receptors on myelinated spinal cord axons: II. AMPA and GluR5 receptors. Ann. Neurol. 2009, 65, 160-166. [CrossRef] [PubMed]

65. Wosik, K.; Ruffini, F.; Almazan, G.; Olivier, A.; Nalbantoglu, J.; Antel, J.P. Resistance of human adult oligodendrocytes to ampa/kainate receptor-mediated glutamate injury. Brain 2004, 127, 2636-2648. [CrossRef] [PubMed] 
66. Bannerman, P.; Horiuchi, M.; Feldman, D.; Hahn, A.; Itoh, A.; See, J.; Jia, Z.P.; Itoh, T.; Pleasure, D. GluR2-free $\alpha$-amino-3-hydroxy-5-methyl-4-isoxazolepropionate receptors intensify demyelination in experimental autoimmune encephalomyelitis. J. Neurochem. 2007, 102, 1064-1070. [CrossRef] [PubMed]

67. Macrez, R.; Stys, P.K.; Vivien, D.; Lipton, S.A.; Docagne, F. Mechanisms of glutamate toxicity in multiple sclerosis: Biomarker and therapeutic opportunities. Lancet Neurol. 2016, 15, 1089-1102. [CrossRef]

68. Matute, C. Characteristics of acute and chronic kainate excitotoxic damage to the optic nerve. Proc. Natl. Acad. Sci. USA 1998, 95, 10229-10234. [CrossRef] [PubMed]

69. Alberdi, E.; Sánchez-Gómez, M.V.; Torre, I.; Domercq, M.; Pérez-Samartín, A.; Pérez-Cerdá, F.; Matute, C. Activation of kainate receptors sensitizes oligodendrocytes to complement attack. J. Neurosci. 2006, 26, 3220-3228. [CrossRef] [PubMed]

70. Degos, V.; Peineau, S.; Nijboer, C.; Kaindl, A.M.; Sigaut, S.; Favrais, G.; Plaisant, F.; Teissier, N.; Gouadon, E.; Lombet, A.; et al. G protein-coupled receptor kinase 2 and group I metabotropic glutamate receptors mediate inflammation-induced sensitization to excitotoxic neurodegeneration. Ann. Neurol. 2013, 73, 667-678. [CrossRef] [PubMed]

71. Rajda, C.; Majláth, Z.; Pukoli, D.; Vécsei, L. Kynurenines and multiple sclerosis: The dialogue between the immune system and the central nervous system. Int. J. Mol. Sci. 2015, 16, 18270-18282. [CrossRef] [PubMed]

72. Bohár, Z.; Toldi, J.; Fülöp, F.; Vécsei, L. Changing the face of kynurenines and neurotoxicity: Therapeutic considerations. Int. J. Mol. Sci 2015, 16, 9772-9793. [CrossRef] [PubMed]

73. Majláth, Z.; Toldi, J.; Fülöp, F.; Vécsei, L. Excitotoxic mechanisms in non-motor dysfunctions and levodopa-induced dyskinesia in Parkinson's disease: The role of the interaction between the dopaminergic and the kynurenine system. Curr. Med. Chem. 2016, 23, 874-883. [CrossRef] [PubMed]

74. Török, N.; Majláth, Z.; Fülöp, F.; Toldi, J.; Vécsei, L. Brain aging and disorders of the central nervous system: Kynurenines and drug metabolism. Curr. Drug Metab. 2016, 17, 412-429. [CrossRef] [PubMed]

75. Dezsi, L.; Tuka, B.; Martos, D.; Vecsei, L. Alzheimer's disease, astrocytes and kynurenines. Curr. Alzheimer Res. 2015, 12, 462-480. [CrossRef] [PubMed]

76. Tajti, J.; Majlath, Z.; Szok, D.; Csati, A.; Toldi, J.; Fulop, F.; Vecsei, L. Novel kynurenic acid analogues in the treatment of migraine and neurodegenerative disorders: Preclinical studies and pharmaceutical design. Curr. Pharm. Des. 2015, 21, 2250-2258. [CrossRef] [PubMed]

77. Sas, K.; Robotka, H.; Rózsa, E.; Agoston, M.; Szénási, G.; Gigler, G.; Marosi, M.; Kis, Z.; Farkas, T.; Vécsei, L.; et al. Kynurenine diminishes the ischemia-induced histological and electrophysiological deficits in the rat hippocampus. Neurobiol. Dis. 2008, 32, 302-308. [CrossRef] [PubMed]

78. Robotka, H.; Sas, K.; Agoston, M.; Rózsa, E.; Szénási, G.; Gigler, G.; Vécsei, L.; Toldi, J. Neuroprotection achieved in the ischaemic rat cortex with L-kynurenine sulphate. Life Sci. 2008, 82, 915-919. [CrossRef] [PubMed]

79. Rozsa, E.; Robotka, H.; Nagy, D.; Farkas, T.; Sas, K.; Vecsei, L.; Toldi, J. The pentylenetetrazole-induced activity in the hippocampus can be inhibited by the conversion of L-kynurenine to kynurenic acid: An in vitro study. Brain Res. Bull. 2008, 76, 474-479. [CrossRef] [PubMed]

80. Prescott, C.; Weeks, A.M.; Staley, K.J.; Partin, K.M. Kynurenic acid has a dual action on ampa receptor responses. Neurosci. Lett. 2006, 402, 108-112. [CrossRef] [PubMed]

81. Füvesi, J.; Rajda, C.; Bencsik, K.; Toldi, J.; Vécsei, L. The role of kynurenines in the pathomechanism of amyotrophic lateral sclerosis and multiple sclerosis: Therapeutic implications. J. Neural Transm. 2012, 119, 225-234. [CrossRef] [PubMed]

82. Sundaram, G.; Brew, B.J.; Jones, S.P.; Adams, S.; Lim, C.K.; Guillemin, G.J. Quinolinic acid toxicity on oligodendroglial cells: Relevance for multiple sclerosis and therapeutic strategies. J. Neuroinflamm. 2014, 11, 204. [CrossRef] [PubMed]

83. Cammer, W. Oligodendrocyte killing by quinolinic acid in vitro. Brain Res. 2001, 896, 157-160. [CrossRef]

84. Sharp, C.D.; Hines, I.; Houghton, J.; Warren, A.; Jackson, T.H.; Jawahar, A.; Nanda, A.; Elrod, J.W.; Long, A.; Chi, A.; et al. Glutamate causes a loss in human cerebral endothelial barrier integrity through activation of NMDA receptor. Am. J. Physiol. Heart Circ. Physiol. 2003, 285, H2592-2598. [CrossRef] [PubMed]

85. Mao, P.; Reddy, P.H. Is multiple sclerosis a mitochondrial disease? Biochim. Biophys. Acta 2010, 1802, 66-79. [CrossRef] [PubMed]

86. Mahad, D.; Lassmann, H.; Turnbull, D. Review: Mitochondria and disease progression in multiple sclerosis. Neuropathol. Appl. Neurobiol. 2008, 34, 577-589. [CrossRef] [PubMed] 
87. DiMauro, S.; Schon, E.A. Mitochondrial respiratory-chain diseases. N. Engl. J. Med. 2003, 348, $2656-2668$. [CrossRef] [PubMed]

88. Reddy, P.H. Mitochondrial medicine for aging and neurodegenerative diseases. Neuromol. Med. 2008, 10, 291-315. [CrossRef] [PubMed]

89. Reddy, P.H. Mitochondrial dysfunction in aging and Alzheimer's disease: Strategies to protect neurons. Antioxid. Redox Signal. 2007, 9, 1647-1658. [CrossRef] [PubMed]

90. Reddy, P.H. Mitochondrial oxidative damage in aging and Alzheimer's disease: Implications for mitochondrially targeted antioxidant therapeutics. J. Biomed. Biotechnol. 2006, 2006, 31372. [CrossRef] [PubMed]

91. Ghafourifar, P.; Mousavizadeh, K.; Parihar, M.S.; Nazarewicz, R.R.; Parihar, A.; Zenebe, W.J. Mitochondria in multiple sclerosis. Front. Biosci. 2008, 13, 3116-3126. [CrossRef] [PubMed]

92. Su, K.; Bourdette, D.; Forte, M. Mitochondrial dysfunction and neurodegeneration in multiple sclerosis. Front. Physiol. 2013, 4, 169. [CrossRef] [PubMed]

93. Szalárdy, L.; Zádori, D.; Klivényi, P.; Toldi, J.; Vécsei, L. Electron transport disturbances and neurodegeneration: From albert Szent-Györgyi's concept (Szeged) till novel approaches to boost mitochondrial bioenergetics. Oxid. Med. Cell. Longev. 2015, 2015, 498401. [CrossRef] [PubMed]

94. Valko, M.; Leibfritz, D.; Moncol, J.; Cronin, M.T.; Mazur, M.; Telser, J. Free radicals and antioxidants in normal physiological functions and human disease. Int. J. Biochem. Cell Biol. 2007, 39, 44-84. [CrossRef] [PubMed]

95. Yankovskaya, V.; Horsefield, R.; Törnroth, S.; Luna-Chavez, C.; Miyoshi, H.; Léger, C.; Byrne, B.; Cecchini, G.; Iwata, S. Architecture of succinate dehydrogenase and reactive oxygen species generation. Science 2003, 299, 700-704. [CrossRef] [PubMed]

96. Senoo-Matsuda, N.; Hartman, P.S.; Akatsuka, A.; Yoshimura, S.; Ishii, N. A complex II defect affects mitochondrial structure, leading to ced-3- and ced-4-dependent apoptosis and aging. J. Biol. Chem. 2003, 278, 22031-22036. [CrossRef] [PubMed]

97. Schon, E.A.; Manfredi, G. Neuronal degeneration and mitochondrial dysfunction. J. Clin Investig. 2003, 111, 303-312. [CrossRef] [PubMed]

98. Beal, M.F. Mitochondria take center stage in aging and neurodegeneration. Ann. Neurol. 2005, 58, 495-505. [CrossRef] [PubMed]

99. Witte, M.E.; Mahad, D.J.; Lassmann, H.; van Horssen, J. Mitochondrial dysfunction contributes to neurodegeneration in multiple sclerosis. Trends Mol. Med. 2014, 20, 179-187. [CrossRef] [PubMed]

100. Lu, F.; Selak, M.; O'Connor, J.; Croul, S.; Lorenzana, C.; Butunoi, C.; Kalman, B. Oxidative damage to mitochondrial DNA and activity of mitochondrial enzymes in chronic active lesions of multiple sclerosis. J. Neurol. Sci. 2000, 177, 95-103. [CrossRef]

101. Kalman, B.; Leist, T.P. A mitochondrial component of neurodegeneration in multiple sclerosis. Neuromol. Med. 2003, 3, 147-158. [CrossRef]

102. Nikić, I.; Merkler, D.; Sorbara, C.; Brinkoetter, M.; Kreutzfeldt, M.; Bareyre, F.M.; Brück, W.; Bishop, D.; Misgeld, T.; Kerschensteiner, M. A reversible form of axon damage in experimental autoimmune encephalomyelitis and multiple sclerosis. Nat. Med. 2011, 17, 495-499. [CrossRef] [PubMed]

103. Sorbara, C.D.; Wagner, N.E.; Ladwig, A.; Nikić, I.; Merkler, D.; Kleele, T.; Marinković, P.; Naumann, R.; Godinho, L.; Bareyre, F.M.; et al. Pervasive axonal transport deficits in multiple sclerosis models. Neuron 2014, 84, 1183-1190. [CrossRef] [PubMed]

104. Mahad, D.J.; Ziabreva, I.; Campbell, G.; Lax, N.; White, K.; Hanson, P.S.; Lassmann, H.; Turnbull, D.M. Mitochondrial changes within axons in multiple sclerosis. Brain 2009, 132, 1161-1174. [CrossRef] [PubMed]

105. Dutta, R.; Trapp, B.D. Pathogenesis of axonal and neuronal damage in multiple sclerosis. Neurology 2007, 68, S22-S31. [CrossRef] [PubMed]

106. Dutta, R.; McDonough, J.; Yin, X.; Peterson, J.; Chang, A.; Torres, T.; Gudz, T.; Macklin, W.B.; Lewis, D.A.; Fox, R.J.; et al. Mitochondrial dysfunction as a cause of axonal degeneration in multiple sclerosis patients. Ann. Neurol. 2006, 59, 478-489. [CrossRef] [PubMed]

107. Trapp, B.D.; Nave, K.A. Multiple sclerosis: An immune or neurodegenerative disorder? Annu. Rev. Neurosci. 2008, 31, 247-269. [CrossRef] [PubMed]

108. Baines, C.P.; Kaiser, R.A.; Purcell, N.H.; Blair, N.S.; Osinska, H.; Hambleton, M.A.; Brunskill, E.W.; Sayen, M.R.; Gottlieb, R.A.; Dorn, G.W.; et al. Loss of cyclophilin D reveals a critical role for mitochondrial permeability transition in cell death. Nature 2005, 434, 658-662. [CrossRef] [PubMed] 
109. Nakagawa, T.; Shimizu, S.; Watanabe, T.; Yamaguchi, O.; Otsu, K.; Yamagata, H.; Inohara, H.; Kubo, T.; Tsujimoto, Y. Cyclophilin D-dependent mitochondrial permeability transition regulates some necrotic but not apoptotic cell death. Nature 2005, 434, 652-658. [CrossRef] [PubMed]

110. Forte, M.; Gold, B.G.; Marracci, G.; Chaudhary, P.; Basso, E.; Johnsen, D.; Yu, X.; Fowlkes, J.; Rahder, M.; Stem, K.; et al. Cyclophilin D inactivation protects axons in experimental autoimmune encephalomyelitis, an animal model of multiple sclerosis. Proc. Natl. Acad. Sci. USA 2007, 104, 7558-7563. [CrossRef] [PubMed]

111. Harding, A.E.; Sweeney, M.G.; Miller, D.H.; Mumford, C.J.; Kellar-Wood, H.; Menard, D.; McDonald, W.I.; Compston, D.A. Occurrence of a multiple sclerosis-like illness in women who have a leber's hereditary optic neuropathy mitochondrial DNA mutation. Brain 1992, 115 Pt 4, 979-989. [CrossRef] [PubMed]

112. Kalman, B.; Alder, H. Is the mitochondrial DNA involved in determining susceptibility to multiple sclerosis? Acta Neurol. Scand. 1998, 98, 232-237. [CrossRef] [PubMed]

113. Mojon, D.S.; Fujihara, K.; Hirano, M.; Miller, C.; Lincoff, N.S.; Jacobs, L.D.; Greenberg, S.J. Leber's hereditary optic neuropathy mitochondrial DNA mutations in familial multiple sclerosis. Graefes Arch. Clin. Exp. Ophthalmol. 1999, 237, 348-350. [CrossRef] [PubMed]

114. Fischer, M.T.; Sharma, R.; Lim, J.L.; Haider, L.; Frischer, J.M.; Drexhage, J.; Mahad, D.; Bradl, M.; van Horssen, J.; Lassmann, H. Nadph oxidase expression in active multiple sclerosis lesions in relation to oxidative tissue damage and mitochondrial injury. Brain 2012, 135, 886-899. [CrossRef] [PubMed]

115. Witte, M.E.; Geurts, J.J.; de Vries, H.E.; van der Valk, P.; van Horssen, J. Mitochondrial dysfunction: A potential link between neuroinflammation and neurodegeneration? Mitochondrion 2010, 10, 411-418. [CrossRef] [PubMed]

116. Campbell, G.R.; Ziabreva, I.; Reeve, A.K.; Krishnan, K.J.; Reynolds, R.; Howell, O.; Lassmann, H.; Turnbull, D.M.; Mahad, D.J. Mitochondrial DNA deletions and neurodegeneration in multiple sclerosis. Ann. Neurol. 2011, 69, 481-492. [CrossRef] [PubMed]

117. Lucchinetti, C.; Brück, W.; Parisi, J.; Scheithauer, B.; Rodriguez, M.; Lassmann, H. Heterogeneity of multiple sclerosis lesions: Implications for the pathogenesis of demyelination. Ann. Neurol. 2000, 47, 707-717. [CrossRef]

118. Fischer, M.T.; Wimmer, I.; Höftberger, R.; Gerlach, S.; Haider, L.; Zrzavy, T.; Hametner, S.; Mahad, D.; Binder, C.J.; Krumbholz, M.; et al. Disease-specific molecular events in cortical multiple sclerosis lesions. Brain 2013, 136, 1799-1815. [CrossRef] [PubMed]

119. Sadeghian, M.; Mastrolia, V.; Rezaei Haddad, A.; Mosley, A.; Mullali, G.; Schiza, D.; Sajic, M.; Hargreaves, I.; Heales, S.; Duchen, M.R.; et al. Mitochondrial dysfunction is an important cause of neurological deficits in an inflammatory model of multiple sclerosis. Sci. Rep. 2016, 6, 33249. [CrossRef] [PubMed]

120. Qi, X.; Lewin, A.S.; Sun, L.; Hauswirth, W.W.; Guy, J. Mitochondrial protein nitration primes neurodegeneration in experimental autoimmune encephalomyelitis. J. Biol. Chem. 2006, 281, 31950-31962. [CrossRef] [PubMed]

121. Redford, E.J.; Kapoor, R.; Smith, K.J. Nitric oxide donors reversibly block axonal conduction: Demyelinated axons are especially susceptible. Brain 1997, 120, 2149-2157. [CrossRef] [PubMed]

122. Shrager, P.; Custer, A.W.; Kazarinova, K.; Rasband, M.N.; Mattson, D. Nerve conduction block by nitric oxide that is mediated by the axonal environment. J. Neurophysiol. 1998, 79, 529-536. [PubMed]

123. Cassina, A.M.; Hodara, R.; Souza, J.M.; Thomson, L.; Castro, L.; Ischiropoulos, H.; Freeman, B.A.; Radi, R. Cytochrome C nitration by peroxynitrite. J. Biol. Chem. 2000, 275, 21409-21415. [CrossRef] [PubMed]

124. Brown, G.C.; Borutaite, V. Inhibition of mitochondrial respiratory complex I by nitric oxide, peroxynitrite and S-nitrosothiols. Biochim. Biophys. Acta 2004, 1658, 44-49. [CrossRef] [PubMed]

125. Yamamoto, T.; Maruyama, W.; Kato, Y.; Yi, H.; Shamoto-Nagai, M.; Tanaka, M.; Sato, Y.; Naoi, M. Selective nitration of mitochondrial complex I by peroxynitrite: Involvement in mitochondria dysfunction and cell death of dopaminergic SH-SY5Y cells. J. Neural Transm. 2002, 109, 1-13. [CrossRef] [PubMed]

126. Phaniendra, A.; Jestadi, D.B.; Periyasamy, L. Free radicals: Properties, sources, targets, and their implication in various diseases. Indian J. Clin. Biochem. 2015, 30, 11-26. [CrossRef] [PubMed]

127. Karg, E.; Klivényi, P.; Németh, I.; Bencsik, K.; Pintér, S.; Vécsei, L. Nonenzymatic antioxidants of blood in multiple sclerosis. J. Neurol. 1999, 246, 533-539. [CrossRef] [PubMed]

128. Burton, G.W.; Cheng, S.C.; Webb, A.; Ingold, K.U. Vitamin E in young and old human red blood cells. Biochim. Biophys. Acta 1986, 860, 84-90. [CrossRef]

129. Pollack, M.; Leeuwenburgh, C. Molecular Mechanisms of Oxidative Stress in Aging: Free Radicals, Aging, Antioxidants and Disease; Online-Datei; Elsevier: Amsterdam, The Netherlands, 2000. 
130. Gonsette, R.E. Neurodegeneration in multiple sclerosis: The role of oxidative stress and excitotoxicity. J. Neurol. Sci. 2008, 274, 48-53. [CrossRef] [PubMed]

131. Ljubisavljevic, S.; Stojanovic, I.; Pavlovic, D.; Sokolovic, D.; Stevanovic, I. Aminoguanidine and $\mathrm{N}$-acetyl-cysteine supress oxidative and nitrosative stress in EAE rat brains. Redox Rep. 2011, 16, 166-172. [CrossRef] [PubMed]

132. Morales Pantoja, I.E.; Hu, C.L.; Perrone-Bizzozero, N.I.; Zheng, J.; Bizzozero, O.A. Nrf2-dysregulation correlates with reduced synthesis and low glutathione levels in experimental autoimmune encephalomyelitis. J. Neurochem. 2016, 139, 640-650. [CrossRef] [PubMed]

133. Xue, H.; Ren, H.; Zhang, L.; Sun, X.; Wang, W.; Zhang, S.; Zhao, J.; Ming, L. $\alpha$-Tocopherol ameliorates experimental autoimmune encephalomyelitis through the regulation of th1 cells. Iran. J. Basic Med. Sci. 2016, 19, 561-566. [PubMed]

134. Liu, Y.; Liu, J.; Tetzlaff, W.; Paty, D.W.; Cynader, M.S. Biliverdin reductase, a major physiologic cytoprotectant, suppresses experimental autoimmune encephalomyelitis. Free Radic. Biol. Med. 2006, 40, 960-967. [CrossRef] [PubMed]

135. Ghaiad, H.R.; Nooh, M.M.; El-Sawalhi, M.M.; Shaheen, A.A. Resveratrol promotes remyelination in cuprizone model of multiple sclerosis: Biochemical and histological study. Mol. Neurobiol. 2016. [CrossRef] [PubMed]

136. Kuo, P.C.; Brown, D.A.; Scofield, B.A.; Yu, I.C.; Chang, F.L.; Wang, P.Y.; Yen, J.H. 3H-1,2-dithiole3-thione as a novel therapeutic agent for the treatment of experimental autoimmune encephalomyelitis. Brain Behav. Immun. 2016, 57, 173-186. [CrossRef] [PubMed]

137. Karg, E.; Klivenyi, P.; Bencsik, K.; Turi, S.; Vecsei, L. $\alpha$-Tocopherol and NADPH in the erythrocytes and plasma of multiple sclerosis patients. Effect of interferon- $\beta-1 B$ treatment. Eur. Neurol. 2003, 50, 215-219. [CrossRef] [PubMed]

138. Løken-Amsrud, K.I.; Myhr, K.M.; Bakke, S.J.; Beiske, A.G.; Bjerve, K.S.; Bjørnarå, B.T.; Hovdal, H.; Lilleås, F.; Midgard, R.; Pedersen, T.; et al. $\alpha$-Tocopherol and mRi outcomes in multiple sclerosis-Association and prediction. PLoS ONE 2013, 8, e54417. [CrossRef] [PubMed]

139. Acar, A.; Ugur Cevik, M.; Evliyaoglu, O.; Uzar, E.; Tamam, Y.; Arıkanoglu, A.; Yucel, Y.; Varol, S.; Onder, H.; Taşdemir, N. Evaluation of serum oxidant/antioxidant balance in multiple sclerosis. Acta Neurol. Belg. 2012, 112, 275-280. [CrossRef] [PubMed]

140. Tasset, I.; Agüera, E.; Sánchez-López, F.; Feijóo, M.; Giraldo, A.I.; Cruz, A.H.; Gascón, F.; Túnez, I. Peripheral oxidative stress in relapsing-remitting multiple sclerosis. Clin. Biochem. 2012, 45, 440-444. [CrossRef] [PubMed]

141. Ortiz, G.G.; Macías-Islas, M.A.; Pacheco-Moisés, F.P.; Cruz-Ramos, J.A.; Sustersik, S.; Barba, E.A.; Aguayo, A. Oxidative stress is increased in serum from mexican patients with relapsing-remitting multiple sclerosis. Dis. Markers 2009, 26, 35-39. [CrossRef] [PubMed]

142. Mitosek-Szewczyk, K.; Gordon-Krajcer, W.; Walendzik, P.; Stelmasiak, Z. Free radical peroxidation products in cerebrospinal fluid and serum of patients with multiple sclerosis after glucocorticoid therapy. Folia Neuropathol. 2010, 48, 116-122. [PubMed]

143. Kemp, K.; Redondo, J.; Hares, K.; Rice, C.; Scolding, N.; Wilkins, A. Oxidative injury in multiple sclerosis cerebellar grey matter. Brain Res. 2016, 1642, 452-460. [CrossRef] [PubMed]

144. Koch, M.; Mostert, J.; Arutjunyan, A.V.; Stepanov, M.; Teelken, A.; Heersema, D.; de Keyser, J. Plasma lipid peroxidation and progression of disability in multiple sclerosis. Eur. J. Neurol. 2007, 14, 529-533. [CrossRef] [PubMed]

145. Adamczyk-Sowa, M.; Sowa, P.; Pierzchala, K.; Polaniak, R.; Labuz-Roszak, B. Antioxidative enzymes activity and malondialdehyde concentration during mitoxantrone therapy in multiple sclerosis patients. J. Physiol. Pharmacol. 2012, 63, 683-690. [PubMed]

146. Choi, I.Y.; Lee, P.; Hughes, A.J.; Denney, D.R.; Lynch, S.G. Longitudinal changes of cerebral glutathione (GSH) levels associated with the clinical course of disease progression in patients with secondary progressive multiple sclerosis. Mult. Scler. 2016. [CrossRef] [PubMed]

147. Sorto-Gomez, T.E.; Ortiz, G.G.; Pacheco-Moises, F.P.; Torres-Sanchez, E.D.; Ramirez-Ramirez, V.; Macias-Islas, M.A.; de la Rosa, A.C.; Velázquez-Brizuela, I.E. Effect of fish oil on glutathione redox system in multiple sclerosis. Am. J. Neurodegener. Dis. 2016, 5, 145-151. [PubMed] 
148. Ghabaee, M.; Jabedari, B.; Al-E-Eshagh, N.; Ghaffarpour, M.; Asadi, F. Serum and cerebrospinal fluid antioxidant activity and lipid peroxidation in guillain-barre syndrome and multiple sclerosis patients. Int. J. Neurosci. 2010, 120, 301-304. [CrossRef] [PubMed]

149. Klivenyi, P.; Karg, E.; Rozsa, C.; Horvath, R.; Komoly, S.; Nemeth, I.; Turi, S.; Vecsei, L. $\alpha$-Tocopherol/lipid ratio in blood is decreased in patients with leber's hereditary optic neuropathy and asymptomatic carriers of the 11778 MTDNA mutation. J. Neurol. Neurosurg. Psychiatry 2001, 70, 359-362. [CrossRef] [PubMed]

150. Karg, E.; Németh, I.; Horányi, M.; Pintér, S.; Vécsei, L.; Hollán, S. Diminished blood levels of reduced glutathione and $\alpha$-tocopherol in two triosephosphate isomerase-deficient brothers. Blood Cells Mol. Dis. 2000, 26, 91-100. [CrossRef] [PubMed]

151. Chow, C.K.; Ibrahim, W.; Wei, Z.; Chan, A.C. Vitamin E regulates mitochondrial hydrogen peroxide generation. Free Radic. Biol. Med. 1999, 27, 580-587. [CrossRef]

152. Lass, A.; Sohal, R.S. Electron transport-linked ubiquinone-dependent recycling of $\alpha$-tocopherol inhibits autooxidation of mitochondrial membranes. Arch. Biochem. Biophys. 1998, 352, 229-236. [CrossRef] [PubMed]

153. Besler, H.T.; Comoğlu, S.; Okçu, Z. Serum levels of antioxidant vitamins and lipid peroxidation in multiple sclerosis. Nutr. Neurosci. 2002, 5, 215-220. [CrossRef] [PubMed]

154. Mai, J.; Sørensen, P.S.; Hansen, J.C. High dose antioxidant supplementation to MS patients. Effects on glutathione peroxidase, clinical safety, and absorption of selenium. Biol. Trace Elem. Res. 1990, 24, 109-117. [CrossRef] [PubMed]

155. Tavazzi, B.; Batocchi, A.P.; Amorini, A.M.; Nociti, V.; D’Urso, S.; Longo, S.; Gullotta, S.; Picardi, M.; Lazzarino, G. Serum metabolic profile in multiple sclerosis patients. Mult. Scler. Int. 2011, 2011, 167156. [CrossRef] [PubMed]

156. Comabella, M.; Montalban, X. Body fluid biomarkers in multiple sclerosis. Lancet Neurol. 2014, 13, 113-126. [CrossRef]

157. Biomarkers Definitions Working Group. Biomarkers and surrogate endpoints: Preferred definitions and conceptual framework. Clin. Pharmacol. Ther. 2001, 69, 89-95.

158. Karussis, D. The diagnosis of multiple sclerosis and the various related demyelinating syndromes: A critical review. J. Autoimmun. 2014, 48-49, 134-142. [CrossRef] [PubMed]

159. Azevedo, C.J.; Kornak, J.; Chu, P.; Sampat, M.; Okuda, D.T.; Cree, B.A.; Nelson, S.J.; Hauser, S.L.; Pelletier, D. In vivo evidence of glutamate toxicity in multiple sclerosis. Ann. Neurol. 2014, 76, 269-278. [CrossRef] [PubMed]

160. MacMillan, E.L.; Tam, R.; Zhao, Y.; Vavasour, I.M.; Li, D.K.; Oger, J.; Freedman, M.S.; Kolind, S.H.; Traboulsee, A.L. Progressive multiple sclerosis exhibits decreasing glutamate and glutamine over two years. Mult. Scler. 2016, 22, 112-116. [CrossRef] [PubMed]

161. Karlík, M.; Valkovič, P.; Hančinová, V.; Krížová, L.; Tóthová, L.; Celec, P. Markers of oxidative stress in plasma and saliva in patients with multiple sclerosis. Clin. Biochem. 2015, 48, 24-28. [CrossRef] [PubMed]

162. Tenorio-Laranga, J.; Peltonen, I.; Keskitalo, S.; Duran-Torres, G.; Natarajan, R.; Männistö, P.T.; Nurmi, A.; Vartiainen, N.; Airas, L.; Elovaara, I.; et al. Alteration of prolyl oligopeptidase and activated $\alpha$-2-macroglobulin in multiple sclerosis subtypes and in the clinically isolated syndrome. Biochem. Pharmacol. 2013, 85, 1783-1794. [CrossRef] [PubMed]

163. Vidaurre, O.G.; Haines, J.D.; Katz Sand, I.; Adula, K.P.; Huynh, J.L.; McGraw, C.A.; Zhang, F.; Varghese, M.; Sotirchos, E.; Bhargava, P.; et al. Cerebrospinal fluid ceramides from patients with multiple sclerosis impair neuronal bioenergetics. Brain 2014, 137, 2271-2286. [CrossRef] [PubMed]

164. Parajuli, B.; Horiuchi, H.; Mizuno, T.; Takeuchi, H.; Suzumura, A. CCL11 enhances excitotoxic neuronal death by producing reactive oxygen species in microglia. Glia 2015, 63, 2274-2284. [CrossRef] [PubMed]

165. Ljubisavljevic, S.; Stojanovic, I.; Vojinovic, S.; Stojanov, D.; Stojanovic, S.; Cvetkovic, T.; Savic, D.; Pavlovic, D. The patients with clinically isolated syndrome and relapsing remitting multiple sclerosis show different levels of advanced protein oxidation products and total thiol content in plasma and CSF. Neurochem. Int. 2013, 62, 988-997. [CrossRef] [PubMed]

166. Kallaur, A.P.; Reiche, E.M.; Oliveira, S.R.; Simão, A.N.; Pereira, W.L.; Alfieri, D.F.; Flauzino, T.; Proença, C.M.; Lozovoy, M.A.; Kaimen-Maciel, D.R.; et al. Genetic, immune-inflammatory, and oxidative stress biomarkers as predictors for disability and disease progression in multiple sclerosis. Mol. Neurobiol. 2017, 54, 31-44. [CrossRef] [PubMed] 
167. Sbardella, E.; Greco, A.; Stromillo, M.L.; Prosperini, L.; Puopolo, M.; Cefaro, L.A.; Pantano, P.; de Stefano, N.; Minghetti, L.; Pozzilli, C. Isoprostanes in clinically isolated syndrome and early multiple sclerosis as biomarkers of tissue damage and predictors of clinical course. Mult. Scler. 2013, 19, 411-417. [CrossRef] [PubMed]

168. Teunissen, C.E.; Sombekke, M.; van Winsen, L.; Killestein, J.; Barkhof, F.; Polman, C.H.; Dijkstra, C.D.; Blankenstein, M.A.; Pratico, D. Increased plasma 8,12-iso-iPF2 $\alpha$-VI levels in relapsing multiple sclerosis patients are not predictive of disease progression. Mult. Scler. 2012, 18, 1092-1098. [CrossRef] [PubMed]

169. Polachini, C.R.; Spanevello, R.M.; Zanini, D.; Baldissarelli, J.; Pereira, L.B.; Schetinger, M.R.; da Cruz, I.B.; Assmann, C.E.; Bagatini, M.D.; Morsch, V.M. Evaluation of $\delta$-aminolevulinic dehydratase activity, oxidative stress biomarkers, and vitamin D levels in patients with multiple sclerosis. Neurotox. Res. 2016, 29, 230-242. [CrossRef] [PubMed]

170. Fiorini, A.; Koudriavtseva, T.; Bucaj, E.; Coccia, R.; Foppoli, C.; Giorgi, A.; Schininà, M.E.; Di Domenico, F.; de Marco, F.; Perluigi, M. Involvement of oxidative stress in occurrence of relapses in multiple sclerosis: The spectrum of oxidatively modified serum proteins detected by proteomics and redox proteomics analysis. PLoS ONE 2013, 8, e65184. [CrossRef] [PubMed]

171. Füvesi, J.; Hanrieder, J.; Bencsik, K.; Rajda, C.; Kovács, S.K.; Kaizer, L.; Beniczky, S.; Vécsei, L.; Bergquist, J. Proteomic analysis of cerebrospinal fluid in a fulminant case of multiple sclerosis. Int. J. Mol. Sci. 2012, 13, 7676-7693. [CrossRef] [PubMed]

172. Fitzner, B.; Hecker, M.; Zettl, U.K. Molecular biomarkers in cerebrospinal fluid of multiple sclerosis patients. Autoimmun. Rev. 2015, 14, 903-913. [CrossRef] [PubMed]

173. Kan, Q.C.; Zhang, S.; Xu, Y.M.; Zhang, G.X.; Zhu, L. Matrine regulates glutamate-related excitotoxic factors in experimental autoimmune encephalomyelitis. Neurosci. Lett. 2014, 560, 92-97. [CrossRef] [PubMed]

174. Shijie, J.; Takeuchi, H.; Yawata, I.; Harada, Y.; Sonobe, Y.; Doi, Y.; Liang, J.; Hua, L.; Yasuoka, S.; Zhou, Y.; et al. Blockade of glutamate release from microglia attenuates experimental autoimmune encephalomyelitis in mice. Tohoku J. Exp. Med. 2009, 217, 87-92. [CrossRef] [PubMed]

175. Kanwar, J.R.; Kanwar, R.K.; Krissansen, G.W. Simultaneous neuroprotection and blockade of inflammation reverses autoimmune encephalomyelitis. Brain 2004, 127, 1313-1331. [CrossRef] [PubMed]

176. Wu, H.Q.; Lee, S.C.; Schwarcz, R. Systemic administration of 4-chlorokynurenine prevents quinolinate neurotoxicity in the rat hippocampus. Eur. J. Pharmacol. 2000, 390, 267-274. [CrossRef]

177. Fazio, F.; Lionetto, L.; Curto, M.; Iacovelli, L.; Copeland, C.S.; Neale, S.A.; Bruno, V.; Battaglia, G.; Salt, T.E.; Nicoletti, F. Cinnabarinic acid and xanthurenic acid: Two kynurenine metabolites that interact with metabotropic glutamate receptors. Neuropharmacology 2017, 112 Pt B, 365-372. [CrossRef] [PubMed]

178. Fazio, F.; Zappulla, C.; Notartomaso, S.; Busceti, C.; Bessede, A.; Scarselli, P.; Vacca, C.; Gargaro, M.; Volpi, C.; Allegrucci, M.; et al. Cinnabarinic acid, an endogenous agonist of type-4 metabotropic glutamate receptor, suppresses experimental autoimmune encephalomyelitis in mice. Neuropharmacology 2014, 81, 237-243. [CrossRef] [PubMed]

179. Vécsei, L. Kynurenines and the nervous system: Therapeutic perspectives. J. Neural Transm. 2012, $119,107$. [CrossRef] [PubMed]

180. Zádori, D.; Klivényi, P.; Toldi, J.; Fülöp, F.; Vécsei, L. Kynurenines in Parkinson's disease: Therapeutic perspectives. J. Neural Transm. 2012, 119, 275-283. [CrossRef] [PubMed]

181. Luchtman, D.; Gollan, R.; Ellwardt, E.; Birkenstock, J.; Robohm, K.; Siffrin, V.; Zipp, F. In vivo and in vitro effects of multiple sclerosis immunomodulatory therapeutics on glutamatergic excitotoxicity. J. Neurochem. 2016, 136, 971-980. [CrossRef] [PubMed]

182. Besong, G.; Battaglia, G.; D’Onofrio, M.; di Marco, R.; Ngomba, R.T.; Storto, M.; Castiglione, M.; Mangano, K.; Busceti, C.L.; Nicoletti, F.R.; et al. Activation of group III metabotropic glutamate receptors inhibits the production of rantes in glial cell cultures. J. Neurosci. 2002, 22, 5403-5411. [PubMed]

183. Villoslada, P.; Arrondo, G.; Sepulcre, J.; Alegre, M.; Artieda, J. Memantine induces reversible neurologic impairment in patients with MS. Neurology 2009, 72, 1630-1633. [CrossRef] [PubMed]

184. Qi, X.; Lewin, A.S.; Sun, L.; Hauswirth, W.W.; Guy, J. Suppression of mitochondrial oxidative stress provides long-term neuroprotection in experimental optic neuritis. Investig. Ophthalmol. Vis. Sci. 2007, 48, 681-691. [CrossRef] [PubMed] 
185. Su, K.G.; Savino, C.; Marracci, G.; Chaudhary, P.; Yu, X.; Morris, B.; Galipeau, D.; Giorgio, M.; Forte, M.; Bourdette, D. Genetic inactivation of the p66 isoform of shca is neuroprotective in a murine model of multiple sclerosis. Eur. J. Neurosci. 2012, 35, 562-571. [CrossRef] [PubMed]

186. Davies, A.L.; Desai, R.A.; Bloomfield, P.S.; McIntosh, P.R.; Chapple, K.J.; Linington, C.; Fairless, R.; Diem, R.; Kasti, M.; Murphy, M.P.; et al. Neurological deficits caused by tissue hypoxia in neuroinflammatory disease. Ann. Neurol. 2013, 74, 815-825. [CrossRef] [PubMed]

187. Mao, P.; Manczak, M.; Shirendeb, U.P.; Reddy, P.H. MITOQ, a mitochondria-targeted antioxidant, delays disease progression and alleviates pathogenesis in an experimental autoimmune encephalomyelitis mouse model of multiple sclerosis. Biochim. Biophys. Acta 2013, 1832, 2322-2331. [CrossRef] [PubMed]

188. Hondares, E.; Mora, O.; Yubero, P.; Rodriguez de la Concepción, M.; Iglesias, R.; Giralt, M.; Villarroya, F. Thiazolidinediones and rexinoids induce peroxisome proliferator-activated receptor-coactivator (PGC)- $1 \alpha$ gene transcription: An autoregulatory loop controls PGC- $1 \alpha$ expression in adipocytes via peroxisome proliferator-activated receptor- $\gamma$ coactivation. Endocrinology 2006, 147, 2829-2838. [CrossRef] [PubMed]

189. Jin, F.; Wu, Q.; Lu, Y.F.; Gong, Q.H.; Shi, J.S. Neuroprotective effect of resveratrol on 6-OHDA-induced Parkinson's disease in rats. Eur. J. Pharmacol. 2008, 600, 78-82. [CrossRef] [PubMed]

190. Shindler, K.S.; Ventura, E.; Dutt, M.; Elliott, P.; Fitzgerald, D.C.; Rostami, A. Oral resveratrol reduces neuronal damage in a model of multiple sclerosis. J. Neuroophthalmol. 2010, 30, 328-339. [CrossRef] [PubMed]

191. Linker, R.A.; Lee, D.H.; Demir, S.; Wiese, S.; Kruse, N.; Siglienti, I.; Gerhardt, E.; Neumann, H.; Sendtner, M.; Lühder, F.; et al. Functional role of brain-derived neurotrophic factor in neuroprotective autoimmunity: Therapeutic implications in a model of multiple sclerosis. Brain 2010, 133, 2248-2263. [CrossRef] [PubMed]

192. Lee, D.H.; Geyer, E.; Flach, A.C.; Jung, K.; Gold, R.; Flügel, A.; Linker, R.A.; Lühder, F. Central nervous system rather than immune cell-derived bdnf mediates axonal protective effects early in autoimmune demyelination. Acta Neuropathol. 2012, 123, 247-258. [CrossRef] [PubMed]

193. Jones, J.L.; Anderson, J.M.; Phuah, C.L.; Fox, E.J.; Selmaj, K.; Margolin, D.; Lake, S.L.; Palmer, J.; Thompson, S.J.; Wilkins, A.; et al. Improvement in disability after alemtuzumab treatment of multiple sclerosis is associated with neuroprotective autoimmunity. Brain 2010, 133, 2232-2247. [CrossRef] [PubMed]

194. Thöne, J.; Ellrichmann, G.; Seubert, S.; Peruga, I.; Lee, D.H.; Conrad, R.; Hayardeny, L.; Comi, G.; Wiese, S.; Linker, R.A.; et al. Modulation of autoimmune demyelination by laquinimod via induction of brain-derived neurotrophic factor. Am. J. Pathol. 2012, 180, 267-274. [CrossRef] [PubMed]

195. Lee, D.H.; Gold, R.; Linker, R.A. Mechanisms of oxidative damage in multiple sclerosis and neurodegenerative diseases: Therapeutic modulation via fumaric acid esters. Int. J. Mol. Sci. 2012, 13, 11783-11803. [CrossRef] [PubMed]

196. Linker, R.A.; Lee, D.H.; Ryan, S.; van Dam, A.M.; Conrad, R.; Bista, P.; Zeng, W.; Hronowsky, X.; Buko, A.; Chollate, S.; et al. Fumaric acid esters exert neuroprotective effects in neuroinflammation via activation of the Nrf2 antioxidant pathway. Brain 2011, 134, 678-692. [CrossRef] [PubMed]

197. Scannevin, R.H.; Chollate, S.; Jung, M.Y.; Shackett, M.; Patel, H.; Bista, P.; Zeng, W.; Ryan, S.; Yamamoto, M.; Lukashev, M.; et al. Fumarates promote cytoprotection of central nervous system cells against oxidative stress via the nuclear factor (erythroid-derived 2)-like 2 pathway. J. Pharmacol. Exp. Ther. 2012, 341, 274-284. [CrossRef] [PubMed]

198. Licht-Mayer, S.; Wimmer, I.; Traffehn, S.; Metz, I.; Brück, W.; Bauer, J.; Bradl, M.; Lassmann, H. Cell type-specific Nrf2 expression in multiple sclerosis lesions. Acta Neuropathol. 2015, 130, 263-277. [CrossRef] [PubMed]

199. Talla, V.; Yu, H.; Chou, T.H.; Porciatti, V.; Chiodo, V.; Boye, S.L.; Hauswirth, W.W.; Lewin, A.S.; Guy, J. NADH-dehydrogenase type-2 suppresses irreversible visual loss and neurodegeneration in the EAE animal model of ms. Mol. Ther. 2013, 21, 1876-1888. [CrossRef] [PubMed]

200. Rice, C.M.; Sun, M.; Kemp, K.; Gray, E.; Wilkins, A.; Scolding, N.J. Mitochondrial sirtuins-A new therapeutic target for repair and protection in multiple sclerosis. Eur. J. Neurosci. 2012, 35, 1887-1893. [CrossRef] [PubMed]

201. Tieu, K.; Perier, C.; Caspersen, C.; Teismann, P.; Wu, D.C.; Yan, S.D.; Naini, A.; Vila, M.; Jackson-Lewis, V.; Ramasamy, R.; et al. D- $\beta$-Hydroxybutyrate rescues mitochondrial respiration and mitigates features of Parkinson disease. J. Clin. Investig. 2003, 112, 892-901. [CrossRef] [PubMed] 
202. Sedel, F.; Papeix, C.; Bellanger, A.; Touitou, V.; Lebrun-Frenay, C.; Galanaud, D.; Gout, O.; Lyon-Caen, O.; Tourbah, A. High doses of biotin in chronic progressive multiple sclerosis: A pilot study. Mult. Scler. Relat. Disord. 2015, 4, 159-169. [CrossRef] [PubMed]

203. Haghikia, A.; Gold, R. Multiple sclerosis: TOWER confirms the efficacy of oral teriflunomide in MS. Nat. Rev. Neurol. 2014, 10, 183-184. [CrossRef] [PubMed]

204. Torkildsen, Ø.; Løken-Amsrud, K.I.; Wergeland, S.; Myhr, K.M.; Holmøy, T. Fat-soluble vitamins as disease modulators in multiple sclerosis. Acta Neurol. Scand. Suppl. 2013. [CrossRef] [PubMed]

205. Prinsen, H.; de Graaf, R.A.; Mason, G.F.; Pelletier, D.; Juchem, C. Reproducibility measurement of glutathione, GABA, and glutamate: Towards in vivo neurochemical profiling of multiple sclerosis with MR spectroscopy at 7T. J. Magn. Reson. Imaging 2017, 45, 187-198. [CrossRef] [PubMed]

(C) 2017 by the authors; licensee MDPI, Basel, Switzerland. This article is an open access article distributed under the terms and conditions of the Creative Commons Attribution (CC BY) license (http://creativecommons.org/licenses/by/4.0/). 